\title{
Density-dependent Changes in the Spatial Distributions of Atlantic Cod (Gadus morhua), American Plaice (Hippoglossoides platessoides), and Greenland Halibut (Reinhardtius hippoglossoides) on the Flemish Cap during 1988-2002
}

\author{
Lisa Hendrickson \\ U.S. National Marine Fisheries Service, Northeast Fisheries Science Center \\ 166 Water Street, Woods Hole, MA 02543, USA \\ and \\ Antonio Vázquez \\ Instituto de Investigaciones Marinas, Eduardo Cabello 6 \\ 36208 Vigo, Spain
}

\begin{abstract}
Hendrickson, L. 2005. Density-dependent changes in the spatial distributions of Atlantic cod (Gadus morhua), American plaice (Hippoglossoides platessoides), and Greenland halibut (Reinhardtius hippoglossoides) on the Flemish Cap during 1988-2002. J. Northw. Atl. Fish. Sci., 37: 53-72. doi:10.2960/J.v37.m566
\end{abstract}

\begin{abstract}
The Flemish Cap is an isolated bank located east of the Grand Banks in the Northwest Atlantic Ocean. Research bottom trawl surveys of the Flemish Cap have been conducted in July by the European Union since 1988. Data from these surveys were used to assess changes in the spatial distributions of Atlantic cod (Gadus morhua), American plaice (Hippoglossoides platessoides), and Greenland halibut (Reinhardtius hippoglossoides) during 1988-2002. Kriging and indices of collocation and co-occurrence indicated that cod and plaice distributions have a high degree of overlap and that density-dependent range contraction of both stocks occurred during a time when Greenland halibut, a more common inhabitant of deep water, exhibited range expansion into shallow water on the Cap. However, the timing and locations of these distributional changes were such that little overlap occurred between the distributions of Greenland halibut and either cod or plaice. The range expansion of Greenland halibut was also density-dependent and primarily attributable to young fish (ages 1 and 2 from the 1994 and 1995 year-classes) which prefer shallow water. The range contractions of cod and plaice have persisted since the mid-1990s, and despite fishing moratoria implemented for plaice in 1994 and for cod in 1999, neither stock has shown signs of recovery. Biological and stock assessment implications of these distribution changes are discussed in relation to the lack of recovery.
\end{abstract}

Key words: American plaice, Atlantic cod, collocation, Flemish Cap, Gadus morhua, Greenland halibut, Hippoglossoides platessoides, kriging, range contraction, range expansion, Reinhardtius hippoglossoides, spatial distribution.

\section{Introduction}

The Flemish Cap is an isolated bank, centered at $47^{\circ} \mathrm{N} 45^{\circ} \mathrm{W}$, which is separated from the Grand Banks of the Newfoundland continental shelf by the deeper waters (up to $1500 \mathrm{~m}$ ) of the Flemish Pass. The Cap is a domeshaped feature that consists of a shallow central area (125 to $150 \mathrm{~m}$ ) and a steeply sloped perimeter.

Since 1988, multi-species bottom trawl surveys of the Flemish Cap have been conducted in July by the European Union (EU). During 1988-2002, survey biomass indices indicated a shift in the predominant groundfish species from American plaice (Hippoglossoides platessoides) and
Atlantic cod (Gadus morhua) to Greenland halibut (Reinhardtius hippoglossoides) (Saborido and Vázquez, MS 2003). The Flemish Cap populations of American plaice (Pitt, 1963) and Atlantic cod represent discrete stocks, and during July, both species are distributed entirely within the depth range sampled during the EU survey, 125 to $730 \mathrm{~m}$ (Saborido and Vázquez, MS 2003). Plaice are also distributed within this depth range during winter and are most abundant at depths of 200 to $400 \mathrm{~m}$ with few individuals found at 550 to $728 \mathrm{~m}$ (Bowering and Brodie, 1994). In both summer and winter, plaice are most abundant at depths of 100 to $200 \mathrm{~m}$ on the northern Grand Banks (Morgan and Brodie, 1991). Although plaice have been found in the deeper waters of the Flemish Pass (Iglesias 
et al., 1996), there is no evidence of mixing between the Flemish Cap and Grand Banks populations (Morgan and Bowering MS, 2004). The summer depth distributions of cod populations located within the general latitudinal range of the Flemish Cap tend to be shallow. During summer, cod are distributed at median depths of 144 to $181 \mathrm{~m}$ in the northern Gulf of St. Lawrence (Castonguay et al., 1999) and 46 to $51 \mathrm{~m}$ in the southern Gulf of St. Lawrence (Swain et al., 1998).

Greenland halibut is a deep-water species that generally occurs at depths of $300 \mathrm{~m}$ to $1600 \mathrm{~m}$ (Templeman, 1973). The depth distribution of the Greenland halibut stock extends beyond the boundaries of the Flemish Cap survey area (Dwyer and Bowering, MS 2003). During the late 1980s, a substantial portion of the stock was distributed in the Flemish Pass and on the slope of the Flemish Cap, at depths of 750 to $1500 \mathrm{~m}$; possibly due to a large-scale migration of the stock from northern areas (Bowering and Power, 1995).

All three stocks are under quota management by the Northwest Atlantic Fisheries Organization (NAFO). During 1960-88, cod landings from the Flemish Cap generally ranged between 10000 and 57000 tons and were estimated to range from 29000 to 48000 tons during 1988-95 (Cerviño and Vázquez, MS 2004). Historically, American plaice were primarily taken as by-catch in directed fisheries for cod and Sebastes sp., but catches increased during the late 1980s due to increased freezer trawler effort (Bowering and Brodie, 1994). Thereafter, fishing moratoria were implemented for both stocks, in 1994 for plaice (NAFO, 1994) and in 1999 for cod (NAFO, 1999). Just after the plaice moratorium, in 1995, a fishery for Greenland halibut developed on and around the Flemish Cap (NAFO, 2003). Despite the fishing moratoria, the Flemish Cap stocks of cod and plaice have yet to show signs of recovery from overfishing (Alpoim and Ávila de Melo, MS 2004; Cerviño and Vázquez, MS 2004).

The spatial distributions of demersal fish species affect the catch composition of bottom trawl fisheries (Alverson et al., 1994) and also have important life history and ecological implications. Therefore, an understanding of the temporal changes in the spatial distribution of the three species, before and after implementation of the fishing moratoria, may provide insight into why the Flemish Cap cod and plaice stocks have not recovered. In this study, we use 15 years of research survey data to assess whether the spatial distributions of the three species are associated with changes in abundance and to characterize spatial overlap between their distributions. The potential effects of these distributional changes on the recovery of Flemish Cap cod and plaice stocks are also discussed.

\section{Materials and Methods}

Catch rate data from research bottom trawl surveys conducted during a single season were used to characterize interannual changes in the spatial distribution and relative abundance of Atlantic cod, American plaice and Greenland halibut on the Flemish Cap. Relative abundance (stratified mean number per tow) and biomass (stratified mean kg per tow) indices were computed for each species based on catch rate data from bottom trawl surveys of the Flemish Cap conducted during 1988-2002. The surveys were conducted by the European Union (EU) during a 2.5 to 3 -week period in July and incorporated a stratified-random sampling design with stratification based on depth (Doubleday, 1981; Saborido and Vázquez, MS 2003). Sampling was conducted in nineteen strata ranging in depth from $125 \mathrm{~m}$ to $730 \mathrm{~m}$, encompassing a total area of $36203 \mathrm{~km}^{2}$ (Fig. 1). Station allocation was proportional to stratum area and consisted of a minimum of two stations per stratum. Standardized tows were conducted at 3.5 knots for 30 minutes (a tow distance of $3.24 \mathrm{~km}$ ) and 113 to 121 stations were sampled per year (Fig. 2). Survey gear, vessel characteristics, and sampling methods are described in Saborido and Vázquez (MS 2003).

We used the GLM procedure in SAS (SAS Institute, $1985)$ to test whether interannual changes in the distribution of each species were density-dependent and associated with depth. The model included log-transformed density data (number per tow) as the dependent variable and year and stratum depth range as independent class variables. Stratum depth ranges included: $127-146 \mathrm{~m}, 147-183 \mathrm{~m}$, 184-256 m, 257-366 m, 367-549 m, and 550-730 m. Maps of density data, aggregated across years, were created for each of three length classes, corresponding to ages 1, 2 and 3+ (Alpoim et al., MS 2002), in order to determine whether depth preferences varied by size-class. Annual trends in percent abundance by depth range were also examined. For each species, percent abundance $(P)$ during year $(i)$ in depth range $(j)$ was computed as:

$$
P=\left(\frac{\bar{N}_{i, j} A_{j}}{\left.\sum \bar{N}_{i, j} A_{j}\right)}\right) * 100
$$

where $A_{j}$ is the area of depth range $j$.

\section{Evaluation of Spatial Structure}

The Geostatistical Analyst extension of ArcGIS v8.2 (ESRI, 2001) was used to model interannual changes in the spatial distribution of each species and to produce prediction maps that illustrate such changes. The "ordinary kriging" method (Cressie, 1993) was used to model changes in spatial structure based on density data (number per tow) from the EU surveys. An omni-directional, spherical 


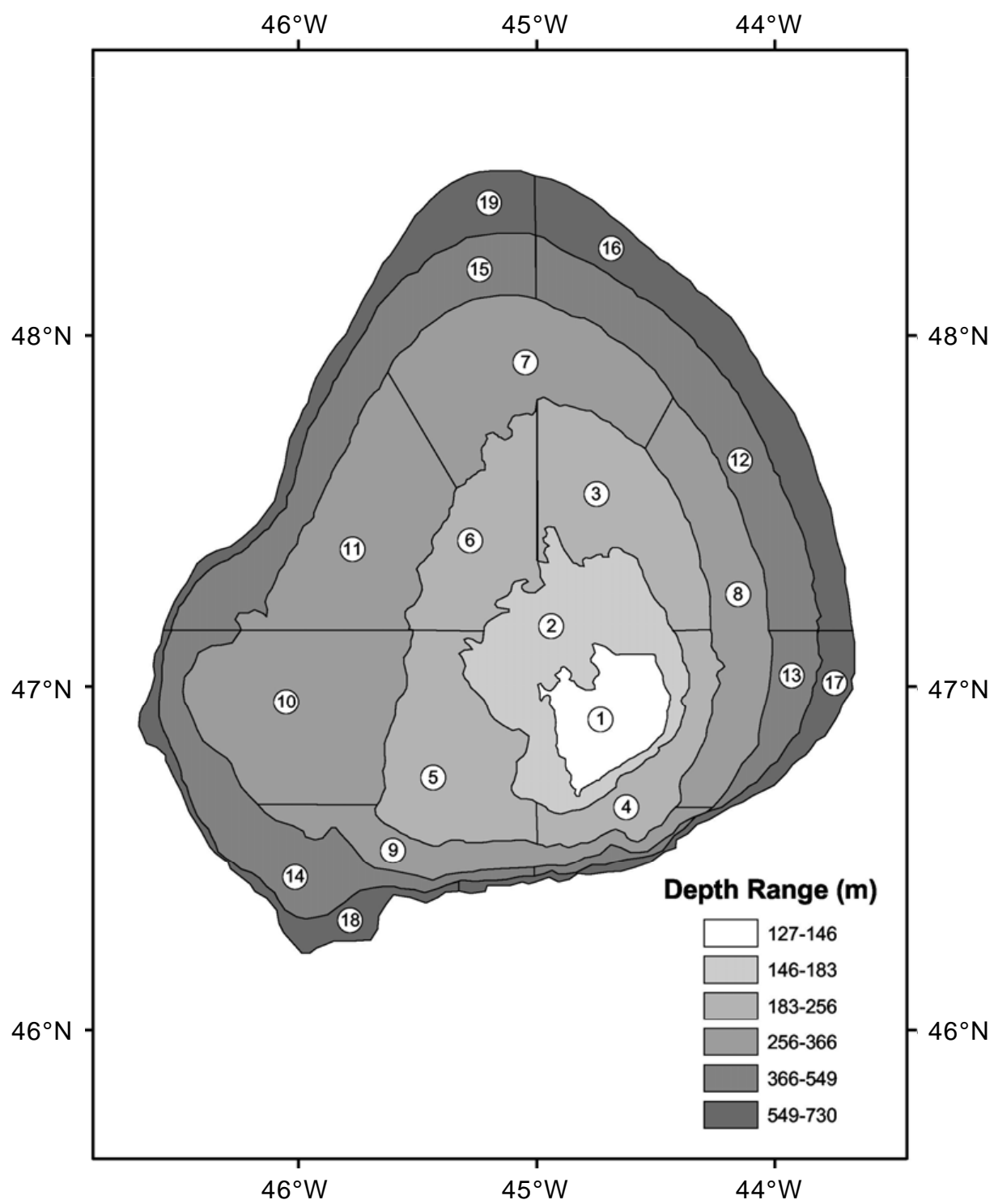

Fig. 1. Depth strata sampled during the July EU bottom trawl surveys of the Flemish Cap in 1988-2002.

semivariogram model was fit to empirical semivariograms of detrended, log-transformed density data (numbers per tow) from the EU survey, by year, for each of the three species. A least squares fit was performed to estimate the parameters of a spherical model defined as:

$$
\gamma(h)=\left\{\begin{array}{cc}
\theta_{s}\left[\frac{3}{2} \frac{b}{\theta_{r}}-\frac{1}{2}\left(\frac{b}{\theta_{r}}\right)^{3}\right] & \text { for } 0 \leq b \leq \theta_{r} \\
\theta_{s} & \text { for } \theta_{r}<b
\end{array}\right.
$$

where $\theta_{s}$ is the sill, $h$ is the lag vector and $b$ is the length of $h$ (distance between two locations), and $\theta_{r}$ is the range.
For each year, the assumption of stationarity of variance was met by log transformation and detrending of the catch rate data. Detrending was necessary because three-dimensional graphs of catch densities by latitude and longitude showed persistent, second-order polynomial spatial trends for all three species. Examination of the influence of directional changes on annual semivariogram clouds did not indicate the presence of anisotropy for any of the three species analyzed. The software uses the sector method to define the search neighbourhood, which consisted of a four-sector ellipse that contained a minimum of three neighbours per sector. Following detrending, point kriging 


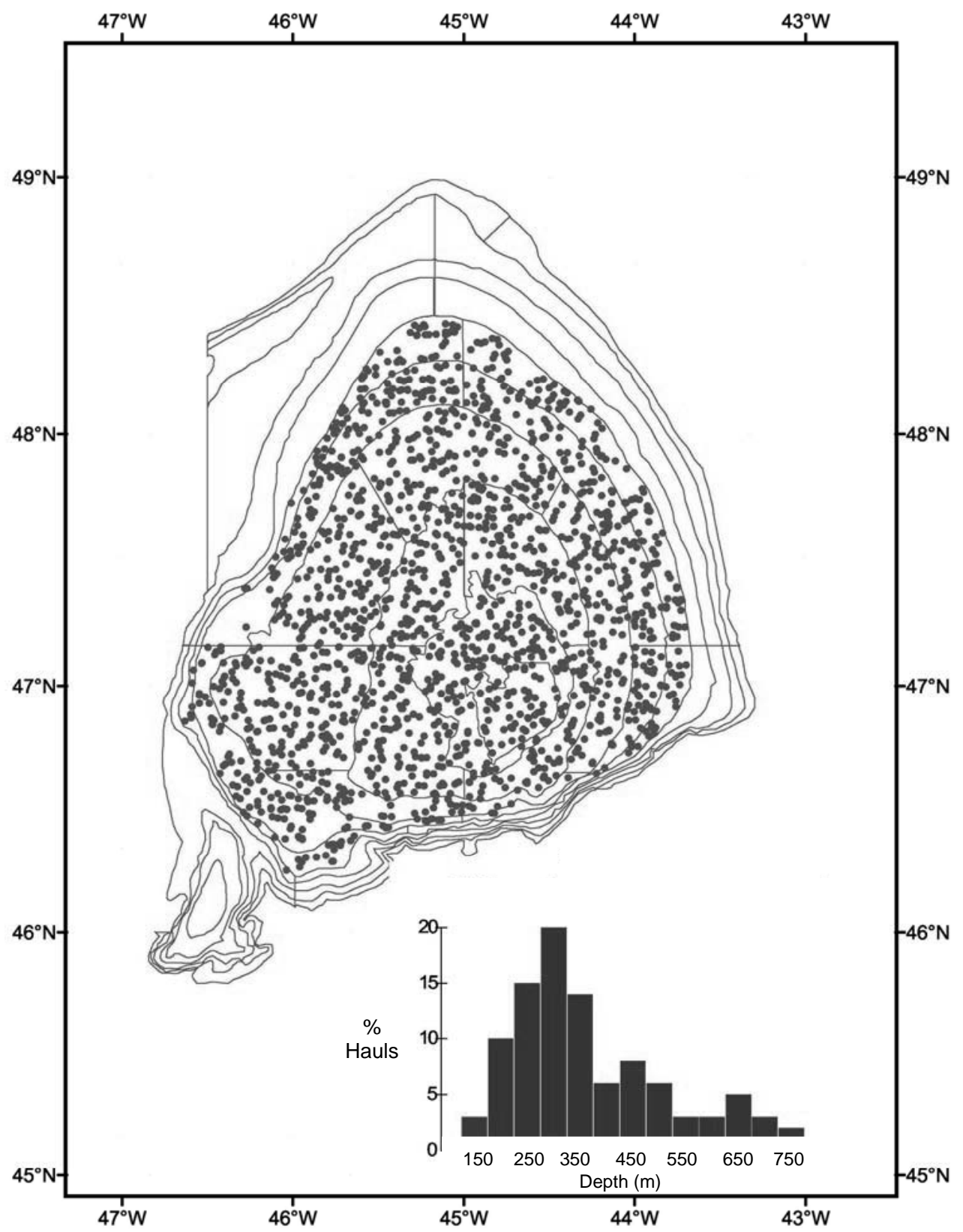

Fig. 2. Stations and depth strata sampled during the July EU bottom trawl surveys of the Flemish Cap in 1988-2002.

was carried out on the residuals. Polynomial trends were added back to the output surface and kriging estimates were back-transformed prior to calculating the final predictions using the following equation (Cressie, 1993):

$$
\hat{Z}\left(s_{0}\right)=\exp \left\{\hat{Z}\left(s_{0}\right)+\sigma_{Y, k}^{2}\left(s_{0}\right) / 2-m_{Y}\right\}
$$

where

$$
\left.m_{Y}=-\left(1-1^{\prime} \Gamma^{-1} \gamma-1\right) / 1^{\prime} \Gamma^{-1} 1\right)
$$

and $\gamma \equiv\left(\gamma\left(s_{0}-s_{1}\right), \ldots, \gamma\left(s_{0}-s_{n}\right)\right)^{\prime}$ and $\Gamma$ is the $n \times n$ matrix whose $(i, j)^{\text {th }}$ element is $\gamma\left(s_{i}-s_{j}\right)$. The software computed optimal lag distances and numbers of lags in addition to providing semivariogram parameter estimates for each year and species.

\section{Relationships Between Species Distributions}

The EU survey data were used to evaluate interannual relationships between species distributions on global and local scales. Relationships between cod and plaice distributions were evaluated on a global scale using 
a collocation index. Local-scale relationships between all three species were evaluated by computing the co-occurrence of species pairs in survey tows. For each tow where more than four individuals of both species were caught, the degree of co-occurrence was computed as a percentage of the density of species A divided by the combined density of both species. The percentage of tows with co-occurrence for each pair of species, as well as the percentage of cod (in numbers) in tows with halibut co-occurrence and the percentage of plaice (in numbers) in tows with halibut co-occurrence were summarized by year and stratum. In addition, we examined the percentage of survey tows with positive catches of each species, by year, as a measure of dispersion because spatial overlap between species distributions is affected by the degree of dispersion of each population.

\section{Collocation of Cod and Plaice}

Annual changes in the collocation of cod and plaice populations were assessed using the method of Bez and Rivoirard (2000). Collocation refers to the way in which two spatial distributions are positioned relative to one another (e.g. between species A and B) and accounts for more than just the degree of spatial overlap between them. The method is robust because it is based on the computation of a distance-based spatial index, the global index of collocation (GIC), which is unaffected by the inclusion of stations where catch rates are zero. Determining whether such stations should be included or excluded can be problematic when defining habitat domains (Rivoirard et al., 2000) and can result in comparing within-habitat zeros of species A with those outside the habitat domain of species B. Geo-referenced abundance data (number per tow) from the EU surveys were used to compute annual GIC values using $\mathrm{R}$ software and geostatistical routines developed by the Centre de Géostatistique in Fontainebleau, France. The GIC is based on computing both the center of gravity and the inertia of a population. The center of gravity $(C G)$ is the mean location of an individual ( $i$ ) sampled at random from a population, the coordinates of which are computed as:

$$
C G=\left\{\begin{array}{l}
\frac{\sum_{i} u_{i} \cdot z_{i}}{\sum_{i} z_{i}} \\
\frac{\sum_{i} v_{i} \cdot z_{i}}{\sum_{i} z_{i}}
\end{array}\right.
$$

where $u_{i}$ is the longitude, $v_{i}$ is the latitude and $z_{i}$ is the observed density at each sample location. Inertia can be represented as an ellipse drawn around two axes that define the directions in which a population is most and least dispersed around the its center of gravity (the intersection of the two axes). Thus, inertia produces a symmetric ellipse around the center of gravity even if the distribution is skewed. Inertia $(I)$ is calculated as the mean square distance between an individual sampled at random $\left(x_{i}\right)$ and the center of gravity of the population $(C G)$, and is computed in surface area units as:

$$
I=\frac{\sum_{i}\left(x_{i}-C G\right)^{2} z_{i}}{\sum_{i} z_{i}}
$$

GIC values can range from 0 to 1 , representing populations that are distributed in two separate locations $(G I C=0)$ and populations with confounded centers of gravity $(G I C=1)$, respectively. Annual GIC values were computed as:

$$
G I C=1-\frac{\Delta C G^{2}}{\Delta C G^{2}+I_{1}+I_{2}}
$$

where $\triangle C G$ is the distance between the centers of gravity for population A and population $\mathrm{B}$, while $I_{1}$ and $I_{2}$ represent the respective inertias of each population.

\section{Results}

During 1989-98, the relative biomass of cod and plaice declined sharply and was coincident with a sharp
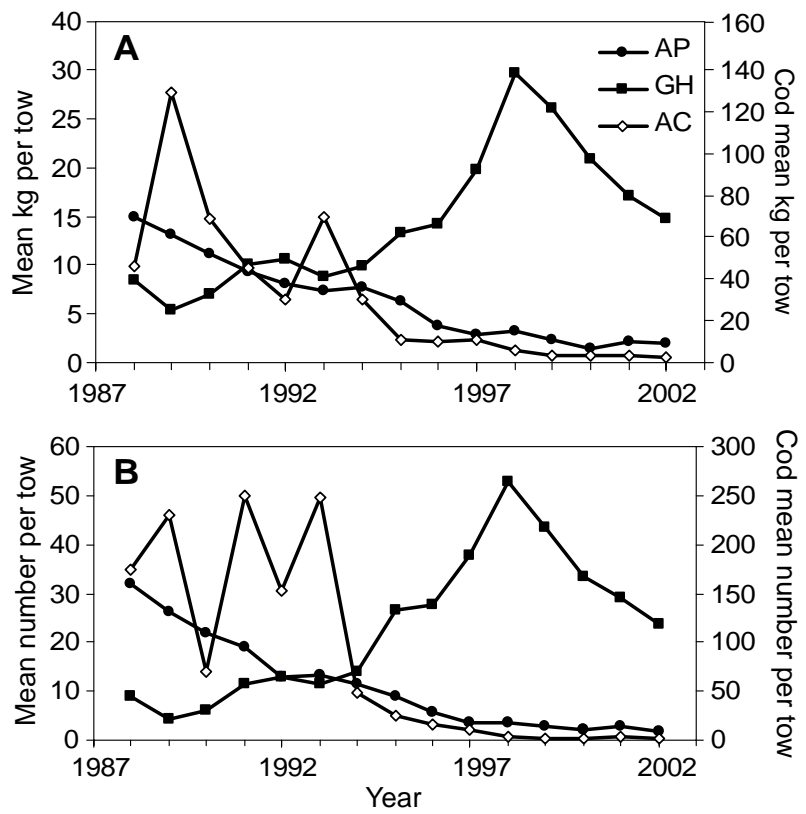

Fig. 3. Relative biomass (A) (stratified mean $\mathrm{kg}$ tow), and (B) abundance indices (stratified mean number per tow) of Atlantic cod (AC), American plaice (AP), and Greenland halibut (GH), during 1988-2002, from the July EU bottom trawl survey of the Flemish Cap. 
increase in Greenland halibut biomass (Fig. 3A). Thereafter, during 1998-2002, cod and plaice biomass indices remained at levels near zero, while Greenland halibut indices declined to their 1996 level. With the exception of cod during 1989-92, relative abundance indices mirrored relative biomass trends (Fig. 3B).

Interannual changes in density were associated with changes in the spatial distributions of the three species. Densities of all three species were significantly associated with stratum depth range and this relationship varied significantly by year (Table 1 ). Year and depth range explained large percentages of the variability in the densities of $\operatorname{cod}(78 \%)$, American plaice $(71 \%)$ and Greenland halibut (77\%) during 1988-2002. Residuals plotted by year and depth range varied without trend for all three species. Prior to 1993 and 1994, cod and plaice, respectively, were most abundant at 183-256 m (Fig. 4). Thereafter, both species were more abundant in shallower areas, at depths less than $183 \mathrm{~m}$. During this same time period, Greenland halibut moved into shallower water and became more abundant at depths of 256-549 m than 549-730 m. After 1995, halibut were most abundant at 256-549 m, while cod and plaice were most abundant at depths less than $256 \mathrm{~m}$. However, halibut abundance at 183-256 m gradually increased from $2 \%$ to $13 \%$ after 1995 .

Maps of kriged abundance indicate that persistent, long-term changes in the distribution of all three species occurred during 1988-2002. For cod and plaice, semivariogram models indicate a gradual shift from a well-defined spatial structure to one that is more random. Examples of semivariogram models fit to cod and plaice abundance data from the early, middle and latter part of the time series highlight this shift (Fig. 5). The range, which can be considered as an indicator of the size of fish aggregations, was greater for both species during the beginning of the time series than during the end. Densities at stations located further than the range distance are not spatially-correlated. For example, plaice were distributed over a larger area prior to 1995 than after. The range of plaice averaged $176 \mathrm{~km}$ during 1988-95 then declined sharply thereafter, averaging $38 \mathrm{~km}$ during 1996-2002 (Table 2). Annual cod distributions were characterized by ranges that were shorter and more variable than those of plaice. Cod ranges fluctuated between $14 \mathrm{~km}$ and $44 \mathrm{~km}$ and were characterized by a series of rises and falls. The range of cod increased during 1988-92, and then declined from $44 \mathrm{~km}$ in 1992 to $19 \mathrm{~km}$ in 1996. During 1997 and 2000, the range of cod declined from $39 \mathrm{~km}$ to $22 \mathrm{~km}$, respectively. Range estimates were high during 1997, 1998 and 2001 due a large nugget effect (random component), indicating little or no spatial structure. The nugget effect quantifies the amount of small-scale spatial structure that is unknown because it is attributable to inter-sample distance and measurement error. As expected, shifts toward a more random semivariogram generally resulted in greater variability in the kriged estimates. An expansion in the range of Greenland halibut occurred coincident with the range contraction observed for cod and plaice.

TABLE 1. General linear model results for the effects of year and depth range on the densities (number per tow) of Atlantic cod, American plaice and Greenland halibut on the Flemish Cap during 1988-2002. Depths ranges, which correspond to the survey strata, are: 127-146 m, 147-183 m, 184-256 m, 257-366 m, 367-549 m, and $550-730 \mathrm{~m}$.

\begin{tabular}{|c|c|c|c|c|c|c|}
\hline Model effects & $\mathrm{df}$ & Type III SS & Mean square & $F$ & $P>F$ & $r^{2}$ \\
\hline \multicolumn{7}{|c|}{ Atlantic cod } \\
\hline Year & 14 & 1144.40 & 81.74 & 44.85 & 0.0001 & 0.78 \\
\hline Depth range & 5 & 6025.16 & 1205.03 & 661.21 & 0.0001 & \\
\hline Year $\times$ depth range & 70 & 1307.89 & 18.68 & 10.25 & 0.0001 & \\
\hline \multicolumn{7}{|c|}{ American plaice } \\
\hline Year & 14 & 458.89 & 32.78 & 23.68 & 0.0001 & 0.71 \\
\hline Depth range & 5 & 3563.98 & 712.79 & 514.93 & 0.0001 & \\
\hline Year $\times$ depth range & 70 & 521.62 & 7.45 & 5.38 & 0.0001 & \\
\hline \multicolumn{7}{|c|}{ Greenland halibut } \\
\hline Year & 14 & 362.54 & 25.90 & 21.27 & 0.0001 & 0.77 \\
\hline Depth range & 5 & 4391.37 & 878.27 & 721.48 & 0.0001 & \\
\hline Year $\times$ depth range & 70 & 581.92 & 8.31 & 6.83 & 0.0001 & \\
\hline
\end{tabular}



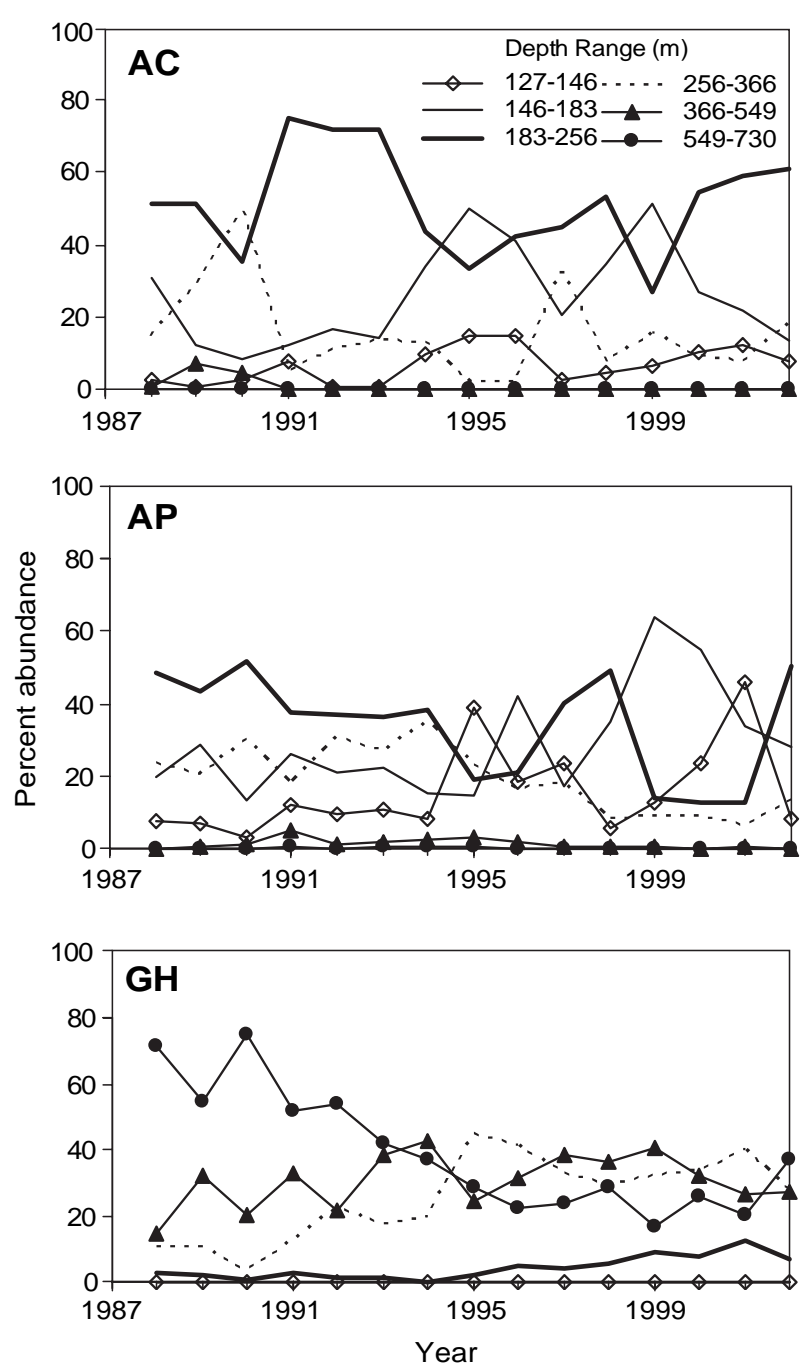

Fig. 4. Trends in annual percent abundance, by depth range, for Atlantic cod (AC), American plaice (AP), and Greenland halibut $(\mathrm{GH})$ on the Flemish Cap during 1988-2002.

The range of Greenland halibut mirrored its abundance trends, exhibiting an increase during 1990 through 1999, from $23 \mathrm{~km}$ to $73 \mathrm{~km}$, then declining thereafter to $45 \mathrm{~km}$ in 2002 (Table 2, Fig. 6).

Maps of kriged abundance indicate that the Flemish Cap stocks of cod and plaice exhibited severe contractions in their distributional areas during 1988-2002. During 1988-94, cod were distributed across a large portion of the Cap and were most abundant at depths of $150 \mathrm{~m}$ to 350 $\mathrm{m}$, where large areas of dense aggregations could be found (Fig. 7). During 1995-2002, the area of cod distribution decreased severely in size and became concentrated on the shallowest portion of the Cap, where aggregations were smaller and less dense, and eventually nonexist- ent. Similarly, a sharp contraction in the area of plaice distribution occurred during 1988-2002 (Fig. 8). Unlike the patchy distribution of cod, plaice were more evenly distributed and characterized by a series of concentric density rings that decreased with increasing depth. During 1988-94, the area and density of the plaice distribution changed from a large area of high density, located across a broad depth range ( $125 \mathrm{~m}$ to $300 \mathrm{~m}$ ), to a small area of low density within the 150-m isobath. During 1995-2002, plaice occurred at very low densities with only one very small, high-density aggregation present within the $150-\mathrm{m}$ isobath during some years.

An expansion in the range of Greenland halibut occurred concurrent with the range contraction of cod and plaice. For all three species, distributional trends can be divided into two periods separated by a transition period during 1993-95. The range of Greenland halibut gradually expanded onto the perimeter of the Cap, from a small area of high abundance at the northernmost tip in 1988, to an area encompassing most of the perimeter of the Cap (to the 600-m isobath) in 1995 (Fig. 9). During 1996-99, the area of distribution expanded further onto the Cap in the form of a circular band. In 1999, this band reached its maximum width and occupied the entire circumference of the Cap. Abundance increased with depth, particularly along the northern perimeter. The area of distribution completely encircled the $250-\mathrm{m}$ isobath, within which was the bathymetric limit of cod and plaice distribution during this time (Fig. 7 and Fig. 8). During 2000-02, the area of Greenland halibut distribution shrank in size, but this reduction did not occur uniformly around the perimeter of the Cap. Instead, large patches of very low abundance occurred within a horseshoe-shaped band of moderate abundance, particularly on the northern portion of the Cap.

The range expansion of Greenland halibut into shallow water, during $1995-98$, was primarily attributable to age 1 and age 2 fish from the 1994 and 1995 year-classes (Fig. 10C). These small fish $(\leq 31 \mathrm{~cm} \mathrm{TL})$ were most abundant at depths of $250 \mathrm{~m}$ to $350 \mathrm{~m}$, while fish larger than $31 \mathrm{~cm}$ were most abundant at depths of $300 \mathrm{~m}$ to $700 \mathrm{~m}$ (Fig. 11). There were very few catches of Greenland halibut at depths less than $200 \mathrm{~m}$. Most of the Greenland halibut caught on the Flemish Cap were immature because few fish were larger than $60 \mathrm{~cm}$ (Alpoim et al., MS 2002), the lower end of the range of $L_{50}$ values reported for females sampled near the Cap (Morgan and Bowering, 1997).

A consistent decline in abundance occurred in all three length classes of American plaice (Fig. 10B). Fish 

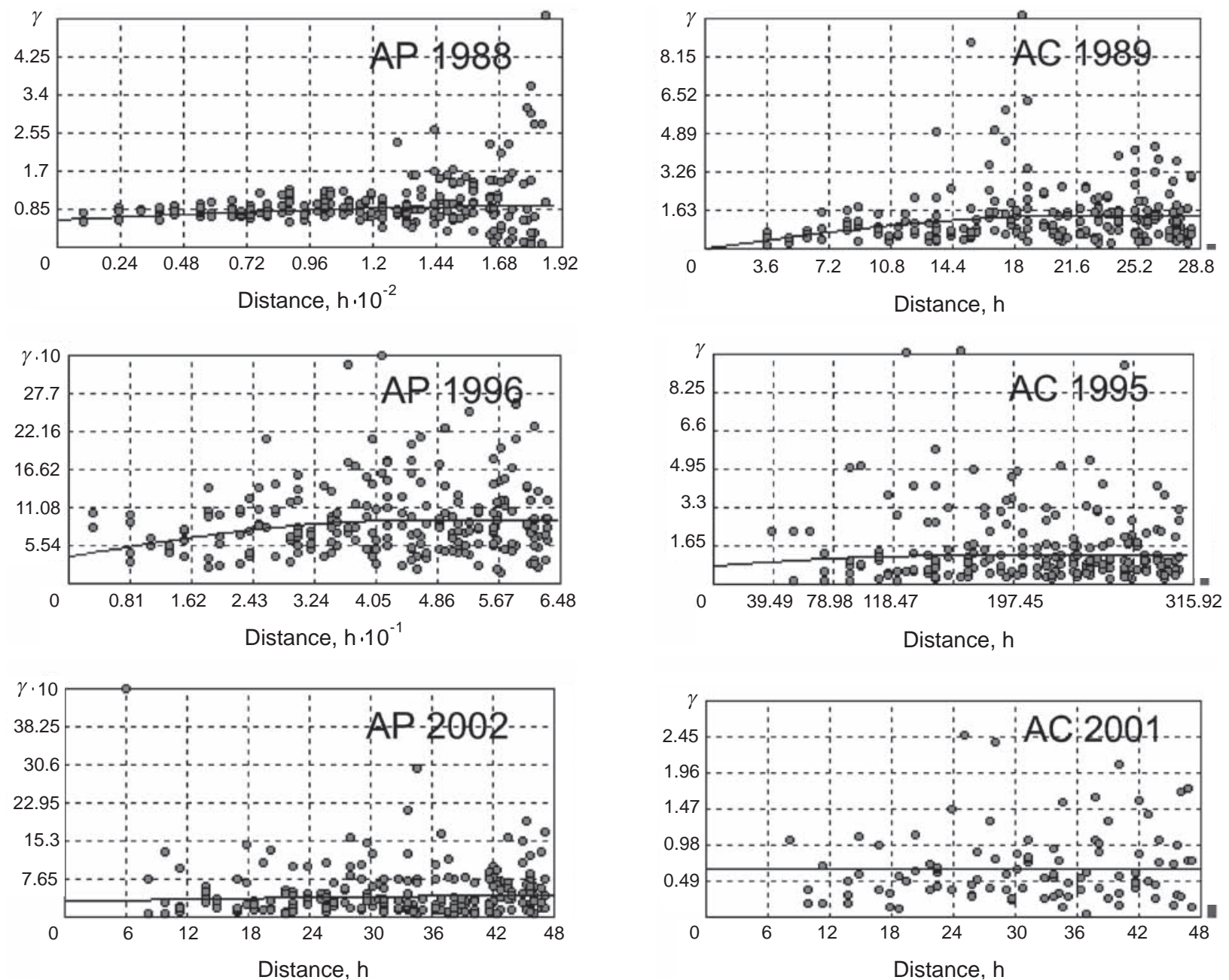

Fig. 5. Examples of semivariograms for spherical models fit to American plaice (AP) and Atlantic cod (AC) density data during a period of rapid decline in abundance for both species on the Flemish Cap.

TABLE 2. Parameter estimates for spherical semivariogram models fit to July abundance data for Atlantic cod, American plaice and Greenland halibut on the Flemish Cap during 1988-2002.

\begin{tabular}{|c|c|c|c|c|c|c|c|c|c|}
\hline \multirow[b]{2}{*}{ Year } & \multicolumn{3}{|c|}{ Atlantic cod } & \multicolumn{3}{|c|}{ American plaice } & \multicolumn{3}{|c|}{ Greenland halibut } \\
\hline & Range (km) & Nugget & Sill & Range (km) & Nugget & Sill & Range (km) & Nugget & Sill \\
\hline 1988 & 26.2 & 0.51 & 1.44 & 186.8 & 0.61 & 0.93 & 47.4 & 0.58 & 0.62 \\
\hline 1989 & 21.0 & 0.00 & 1.40 & 176.9 & 0.49 & 0.61 & 91.0 & 0.28 & 0.60 \\
\hline 1990 & 24.4 & 0.37 & 1.01 & 185.1 & 0.69 & 1.00 & 23.0 & 0.00 & 0.61 \\
\hline 1991 & 31.0 & 0.63 & 1.85 & 67.7 & 0.48 & 0.90 & 40.0 & 0.09 & 0.44 \\
\hline 1992 & 44.3 & 0.32 & 2.93 & 178.5 & 0.64 & 0.74 & 27.7 & 0.24 & 0.71 \\
\hline 1993 & 36.1 & 1.50 & 2.64 & 196.6 & 0.51 & 0.79 & 63.0 & 0.45 & 0.67 \\
\hline 1994 & 18.8 & 0.00 & 1.83 & 192.3 & 0.55 & 0.89 & 29.0 & 0.62 & 0.83 \\
\hline 1995 & 14.8 & 0.79 & 1.23 & 220.7 & 0.75 & 1.04 & 52.0 & 0.15 & 0.95 \\
\hline 1996 & 19.3 & 0.00 & 1.27 & 44.2 & 0.39 & 0.92 & 49.0 & 0.30 & 0.85 \\
\hline 1997 & 39.1 & 0.43 & 0.94 & 23.2 & 0.09 & 0.88 & 37.0 & 0.15 & 0.78 \\
\hline 1998 & 39.7 & 0.27 & 0.60 & 37.0 & 0.68 & 1.36 & 69.0 & 0.18 & 0.73 \\
\hline 1999 & 25.0 & 0.00 & 0.56 & 45.0 & 1.09 & 1.09 & 73.0 & 0.37 & 0.59 \\
\hline 2000 & 22.5 & 0.00 & 0.47 & 34.2 & 0.00 & 0.75 & 70.0 & 0.23 & 0.68 \\
\hline 2001 & 45.6 & 0.66 & 0.66 & 33.3 & 0.00 & 1.08 & 64.0 & 0.01 & 0.92 \\
\hline 2002 & 13.5 & 0.00 & 0.83 & 47.0 & 0.32 & 0.43 & 45.0 & 0.18 & 0.84 \\
\hline
\end{tabular}



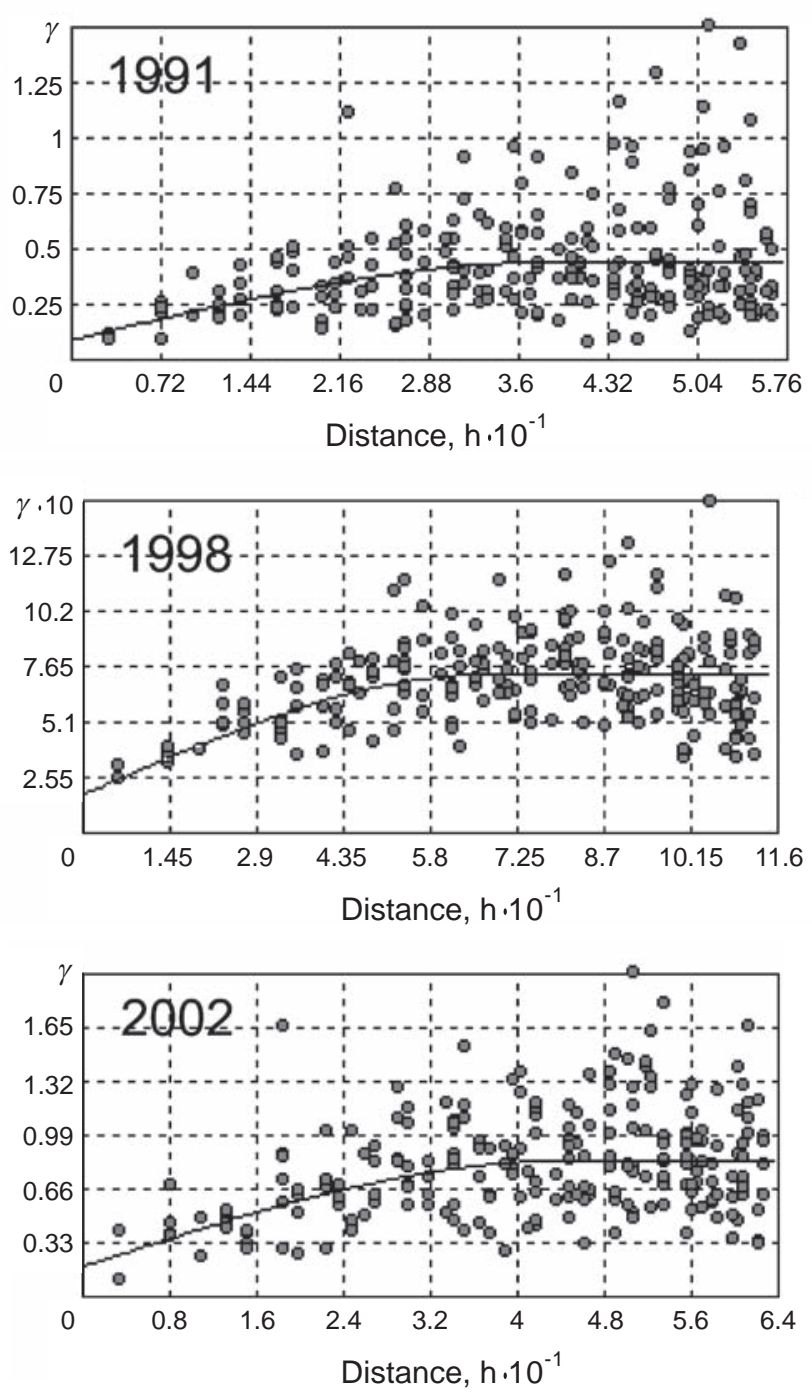

Fig. 6. Examples of semivariograms for spherical models fit to Greenland halibut density data during a period of increasing abundance, in 1989-98, followed by a gradual decline.

larger than $30 \mathrm{~cm}$ TL (age 3+), which dominated the survey catches, showed a preference for the shallow water and were most abundant at depths less than $200 \mathrm{~m}$ (Fig. 12). Unlike American plaice and Greenland halibut, cod did not show depth preferences by size-class (Fig. 13). During 1991-93, most of the cod caught in the survey were smaller than $40 \mathrm{~cm}$ (Fig. 10A) and appeared as high-density aggregations (Fig. 7) of age 1 and age 2 fish from the 1990 and 1991 year-classes (Fig. 10A). After 1994, all three length classes were at similarly low levels of abundance.

\section{Relationships Between Species Distributions}

Collocation indices suggest a high degree of similarity between cod and plaice distributions. During 1988-
2002, annual ellipses of inertia for both species showed a high degree of overlap (Fig. 14A) and GIC values were consistently at or near 1.0 (Fig. 14B). The spatial distributions of cod and plaice became more aggregated while the distribution of halibut became more dispersed. The percentage of survey tows with catches of cod decreased from $85 \%$ in 1990 to $33 \%$ in 2002 (Fig. 15). American plaice showed a similar trend but the decrease occurred later. The percentage of tows with plaice catch decreased from $85 \%$ in 1993 to $35 \%$ in 2000 . In contrast, the distribution of Greenland halibut became more dispersed, and between 1994 and 1998, this species was found in 61\% and $90 \%$ of the tows, respectively.

Cod and plaice co-occurred more frequently, in $24 \%$ of the survey tows conducted during 1988-2002, than did either species with Greenland halibut. Cod and halibut co-occurred in $4 \%$ of the tows and plaice and halibut co-occurred in 3\% of the tows. Co-occurrence varied by year and stratum for all three stocks. The co-occurrence of cod and plaice declined from 59\% in 1988 to near $0 \%$ in 2000 (Fig. 16). This trend was due to a shift, after 1993, from frequent co-occurrence in a large number of strata (strata 1-11 at depths of 127-365 m) to co-occurrence in only a few of the shallowest strata (strata 1-5). After 1998, co-occurrence was only present in stratum 2 (144-181 m), the only stratum where the two species consistently co-occurred throughout the time series. Greenland halibut were never caught on the shallowest part of the Cap (in stratum1), where cod and plaice frequently co-occurred. Greenland halibut and plaice co-occurred in few strata (7-11 and 14) and there has been no co-occurrence since 1998. The percentage of plaice in tows with halibut co-occurrence declined over time, particularly on the southwest side of the Cap in stratum 10 (Fig. 17A). Greenland halibut co-occurred with cod across a broader area, in more strata, on an annual basis than with plaice. The percentage of cod in tows with halibut co-occurrence also declined over time and progressed from deep water (strata 7-15) during 1988-95 to shallower water (strata 3-6, Fig. 17B) thereafter.

\section{Discussion}

Density-dependent changes in the spatial distributions of Atlantic cod, American plaice and Greenland halibut occurred on the Flemish Cap during 1988-2002. For all three species, distributional trends can be divided into two periods, pre- and post-1995. Declines in the abundance of cod and plaice were accompanied by severe range contraction and a breakdown in the spatial structure of both stocks. A similar trend has also been documented for the northern cod stock (Gadus morhua) in NAFO Div. 2J+3KL during 1985-92, coincident with its collapse 

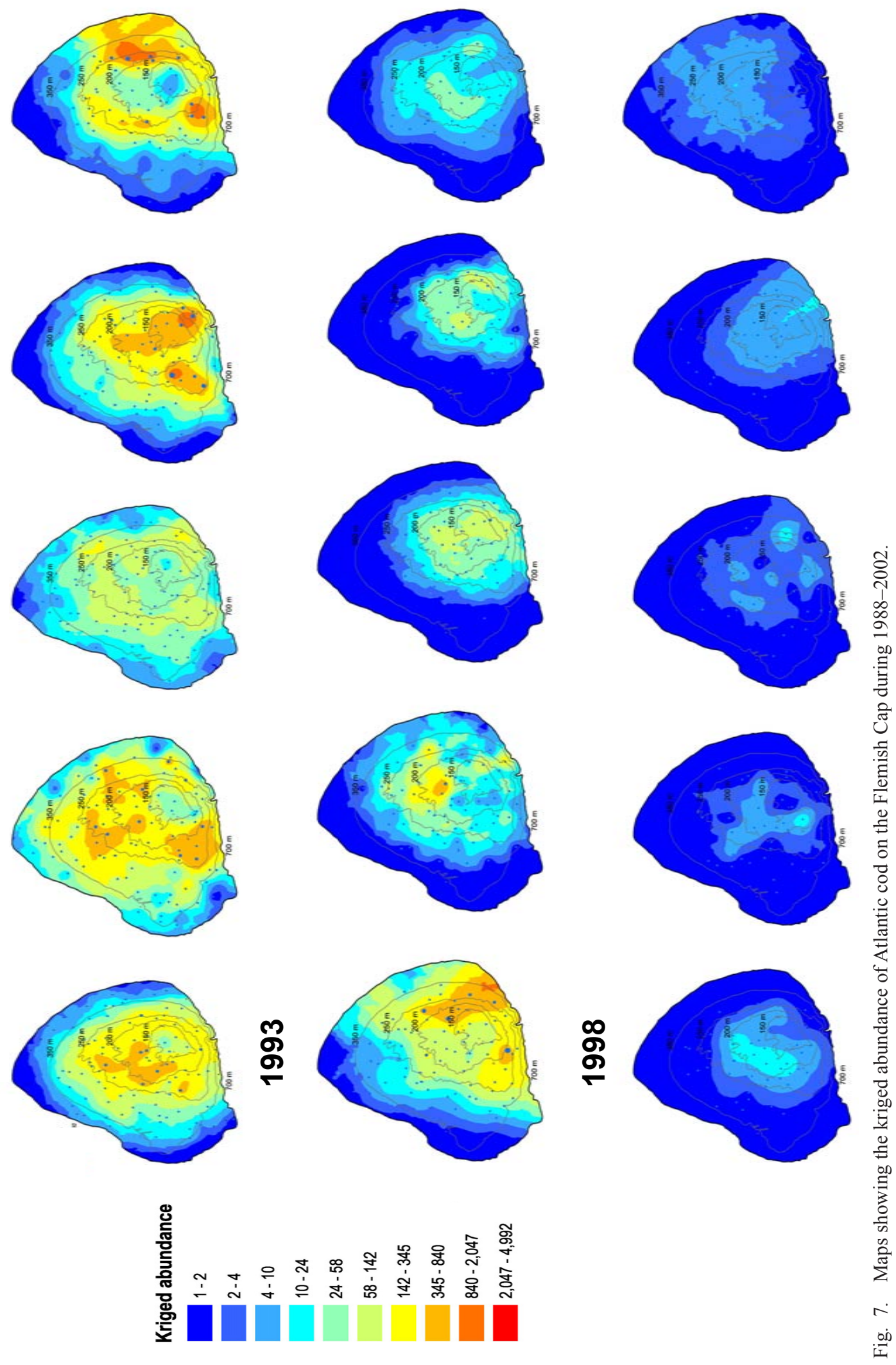

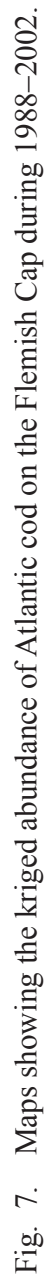
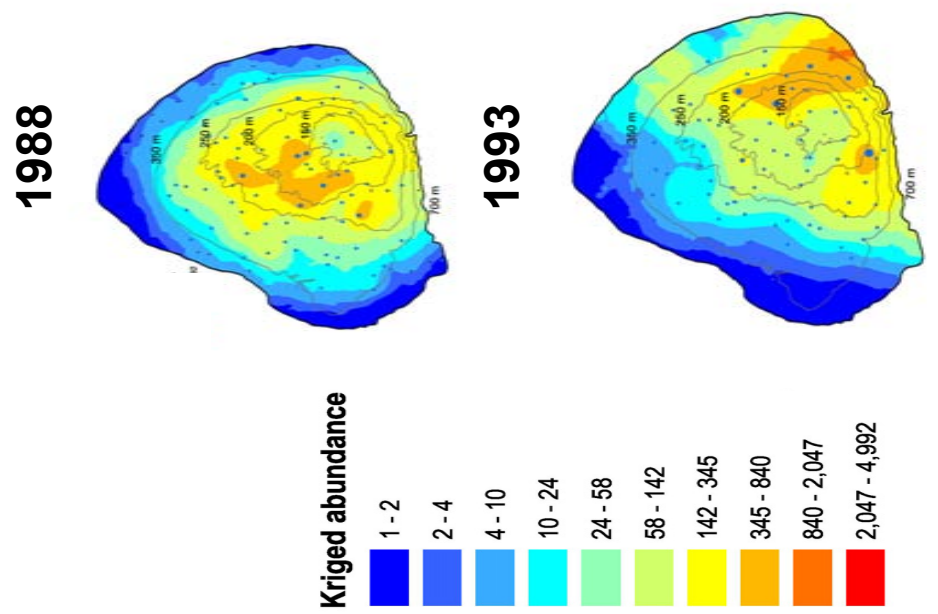
Hendrickson and Vázquez: Changes in the Spatial Distribution on the Flemish Cap
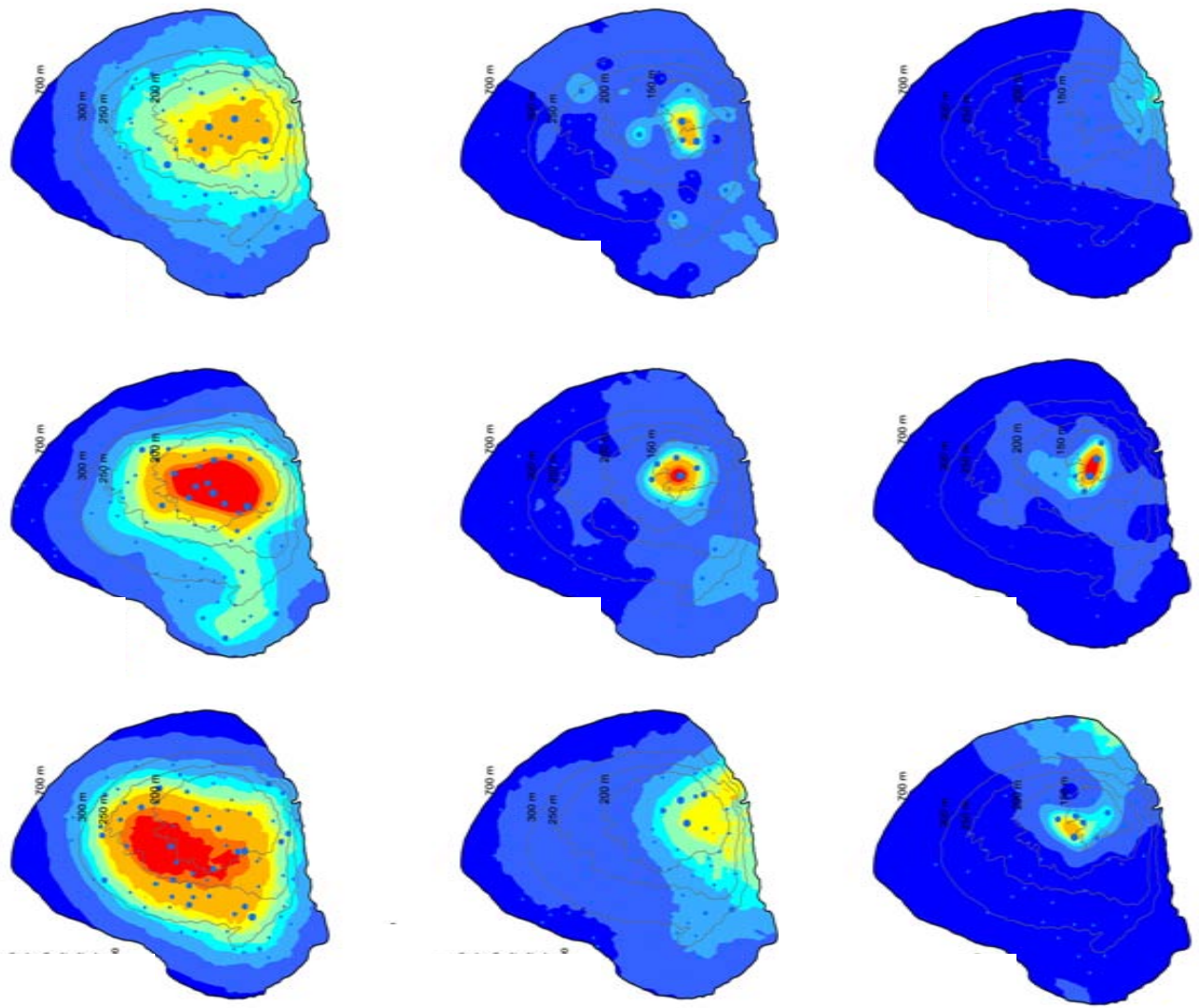

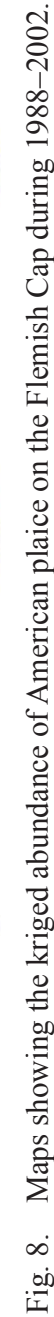
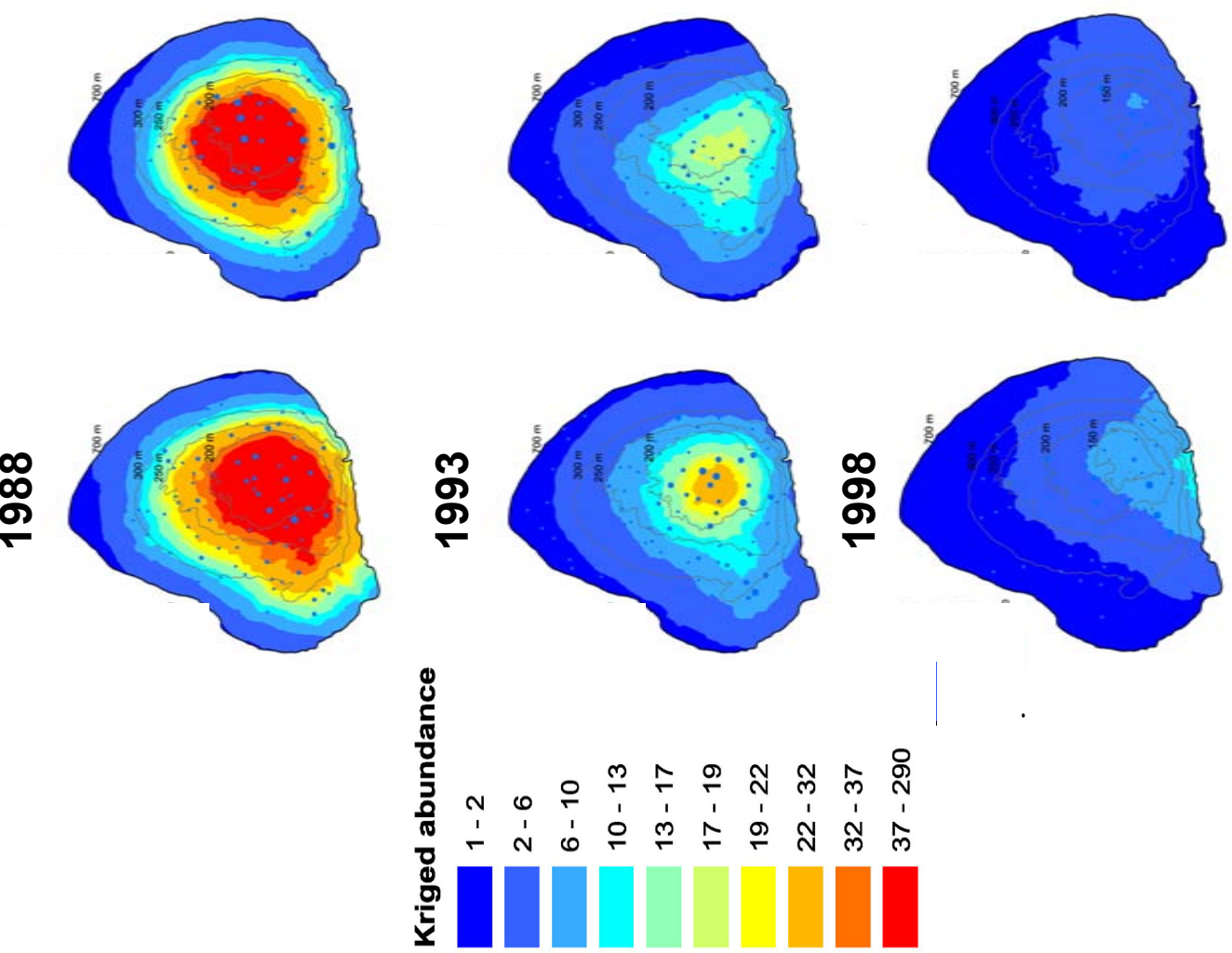

,
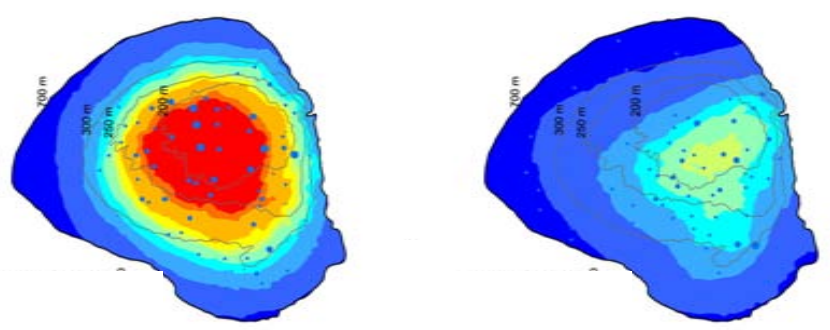

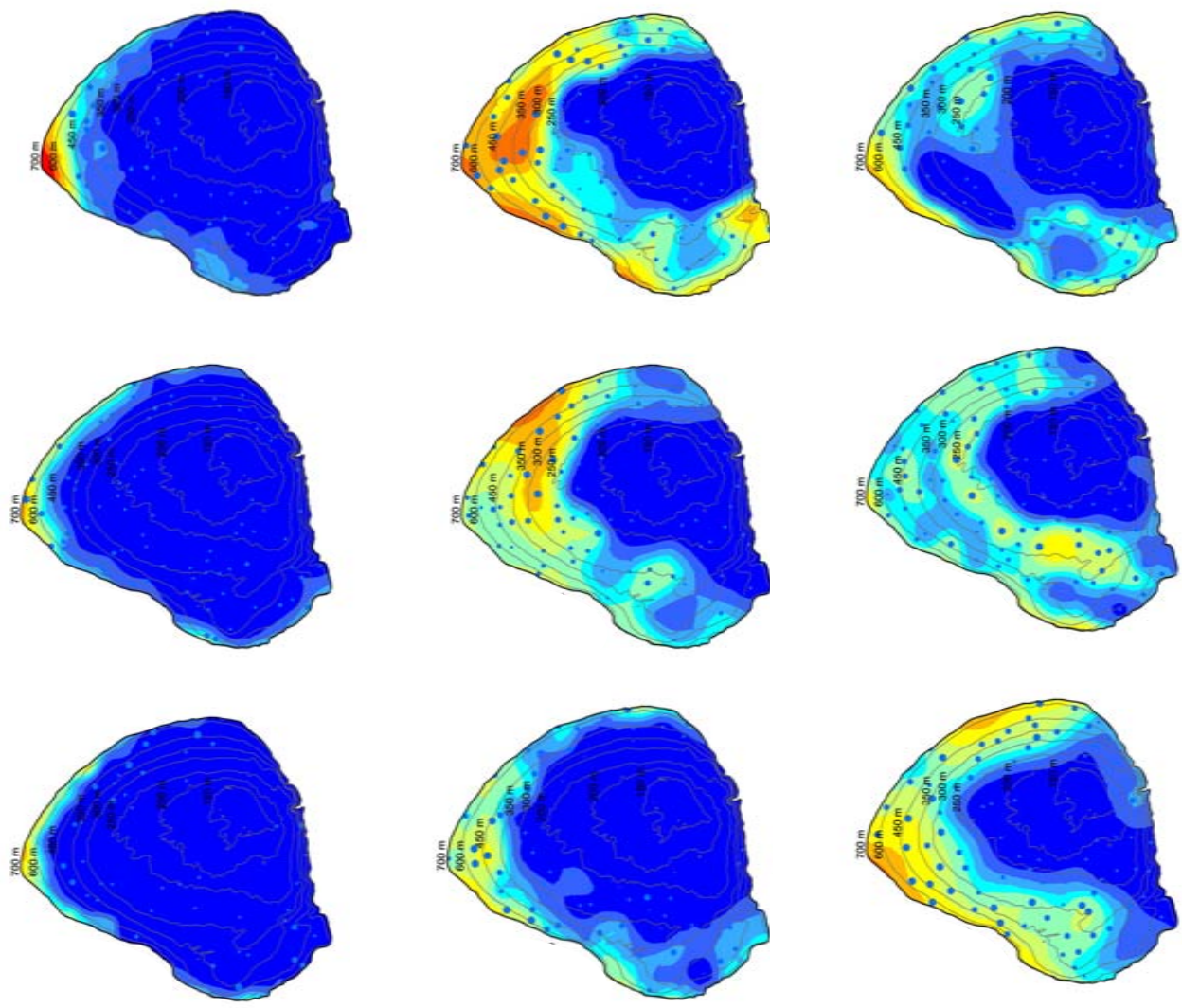

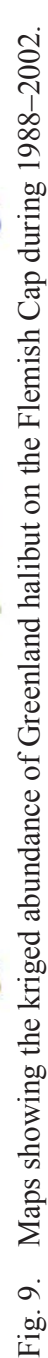
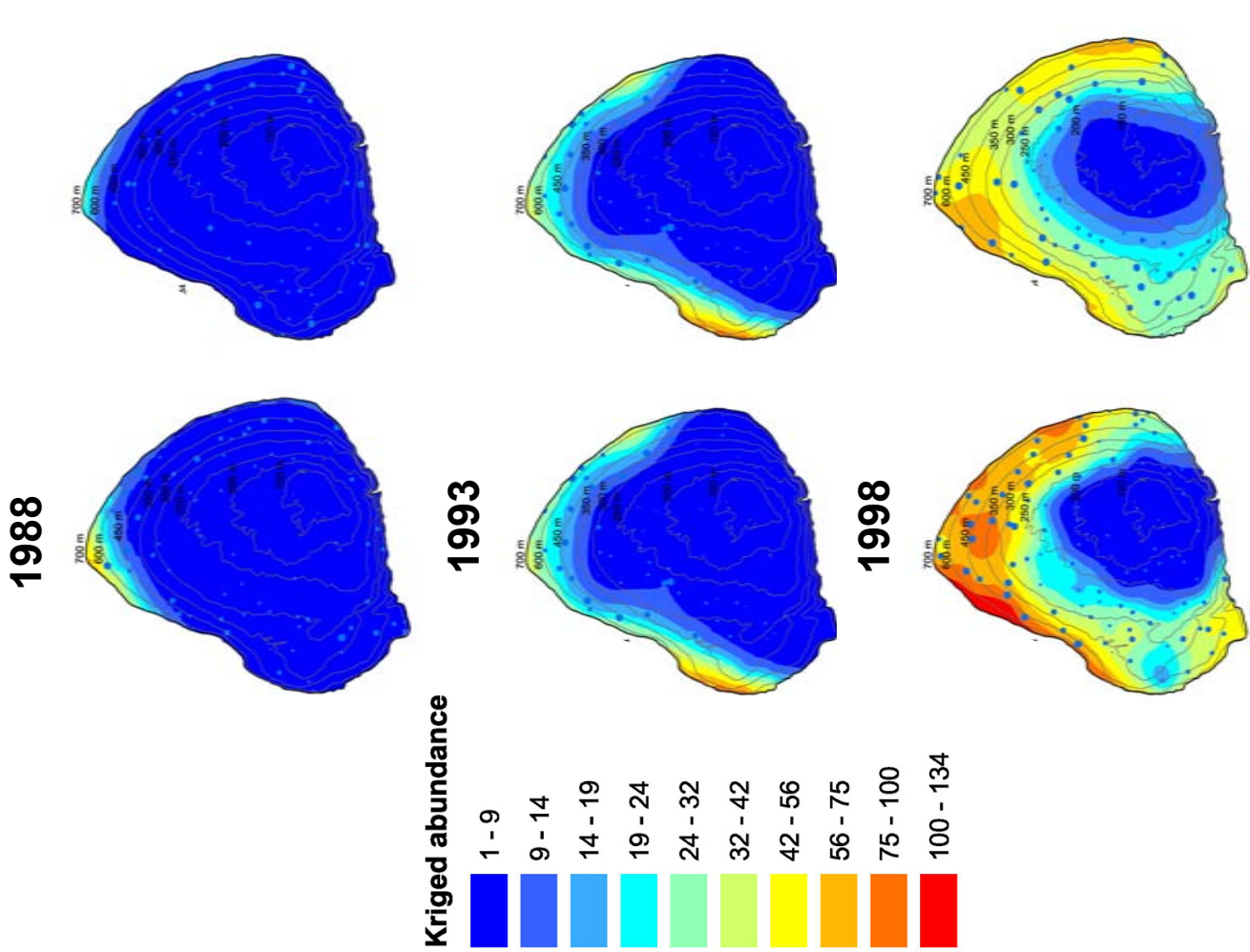

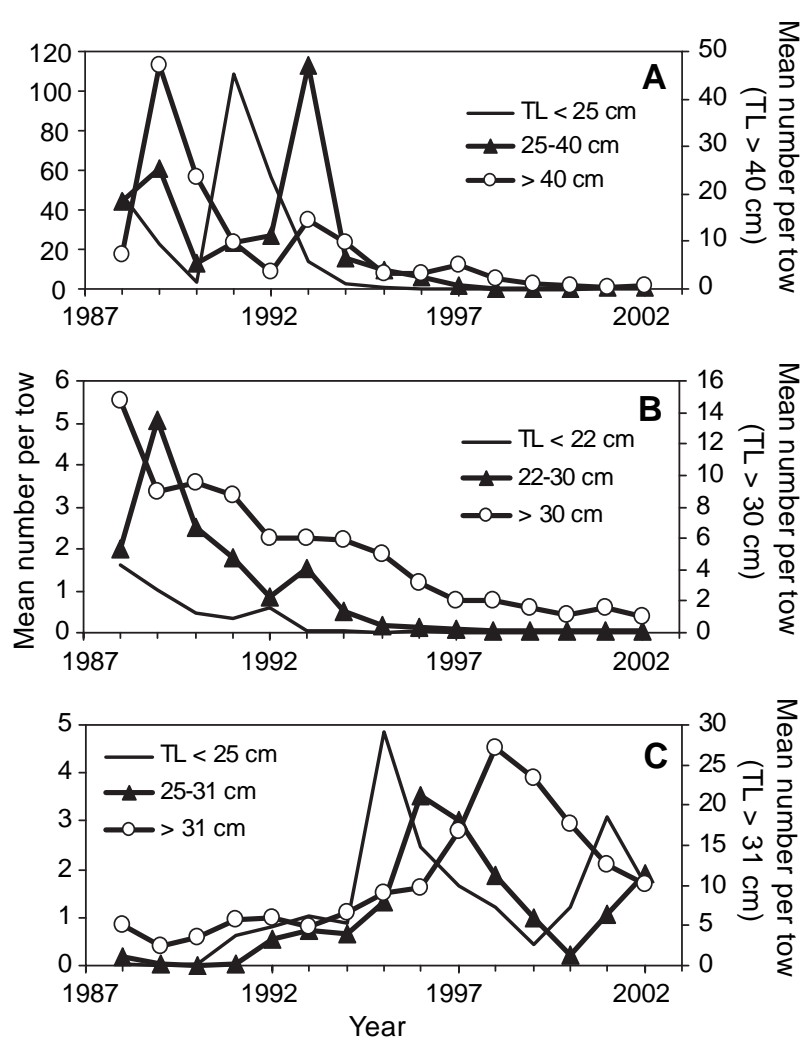

Fig. 10. Relative abundance (stratified mean number per tow), by length class, of (A) Atlantic cod, (B) American plaice, and (C) Greenland halibut on the Flemish Cap during 1988-2002. For each species, the three length classes correspond to ages 1, 2 and 3+.

(Warren, 1997). Global indices of collocation indicate that the Flemish Cap cod and plaice stocks were distributed in similar locations during 1988-2002. However, a more localized index of co-occurrence suggested a decline in the distributional overlap between the two species during this time period and that persistent co-occurrence was limited to depths of 147 to $183 \mathrm{~m}$. During 1988-2002, decreases in the abundance of both stocks coincided with decreases in their areal distributions and both species became concentrated on the shallowest part of the Cap. Prior to 1988, during 1978-85, American plaice were distributed across a broader area and were most abundant on the Cap at depths of 200 to $400 \mathrm{~m}$ (Bowering and Brodie, 1994).

Coincident with the range contraction of cod and plaice, Greenland halibut expanded its range on the Cap into shallower areas that were previously inhabited by cod and plaice. Such broad-scale, within-season distribution shifts can be associated with changes in food and/or space competition or environmental conditions. However, the timing of these shifts was such that the areas in which cod and plaice were distributed showed little overlap with the distribution of Greenland halibut. Thus, it is unlikely that the range contraction of cod and plaice occurred as a result of food and/or space competition with Greenland halibut. On the Flemish Cap, cod and plaice have similar prey preferences (Torres et al., 2000). However, co-occurrence of the two species declined during the study period, suggesting a reduction in food and/or space competition.

Shifts in the spatial distribution of cod may reflect density-dependent changes in temperature preference. Swain and Kramer (1995) found that cod occupy shallow, warm areas when abundance is low and colder, deeper areas when abundance is high in order to reduce metabolic costs as food rations decline. However, such shifts are not likely for American plaice (Swain and Morin, 1996), because plaice prefer cold temperatures regardless of whether rations are high or low (Morgan, 1993). In either case, the distributional shifts of cod and plaice have persisted across years during the summer, when thermohaline conditions near the bottom of the water column are fairly constant on the Flemish Cap. A seasonal thermocline is present on the Cap during May through late August (Gil et al., 2004). There is no seasonal cycle in temperature or salinity at depths below $100 \mathrm{~m}$ (Colburne and Foote, 2000), and at depths below $200 \mathrm{~m}$, average temperature and salinity values recorded during the 1988-2000 EU surveys exhibited little interannual variability (Gil et al., 2004). These trends suggest that factors other than changes in thermohaline conditions are the primary reason for the persistence of the observed distributional changes.

Since the fishing moratoria, neither the cod nor plaice stocks have shown signs of recovery. Post-moratoria levels of spawning stock biomass have continued to remain extremely low, total biomass has continued to decline, and there has been no appreciable recruitment in either stock (Alpoim and Ávila de Melo, MS 2004; Cerviño and Vázquez, MS 2004). Recruitment can be affected by the environment as well as spawning stock size. However, unless the natural mortality rate of mature fish has increased, these negative trends combined with the persistent pattern of range contraction suggest that fishing mortality rates on both stocks continue to be problematic.

Extremely low spawning stock size may be the primary reason for the lack of recovery of cod and plaice stocks. However, the persistent range contraction observed in both stocks also has biological implications that may be linked to stock recovery. The most obvious is the potential for increased vulnerability of aggregations to trawl fisheries (Kulka et al., 1995). In addition, geographic fragmentation of the spawning stock, whereby spawners are concentrated in small patches located further apart, may hinder stock recovery due to: a) reduced demo- 

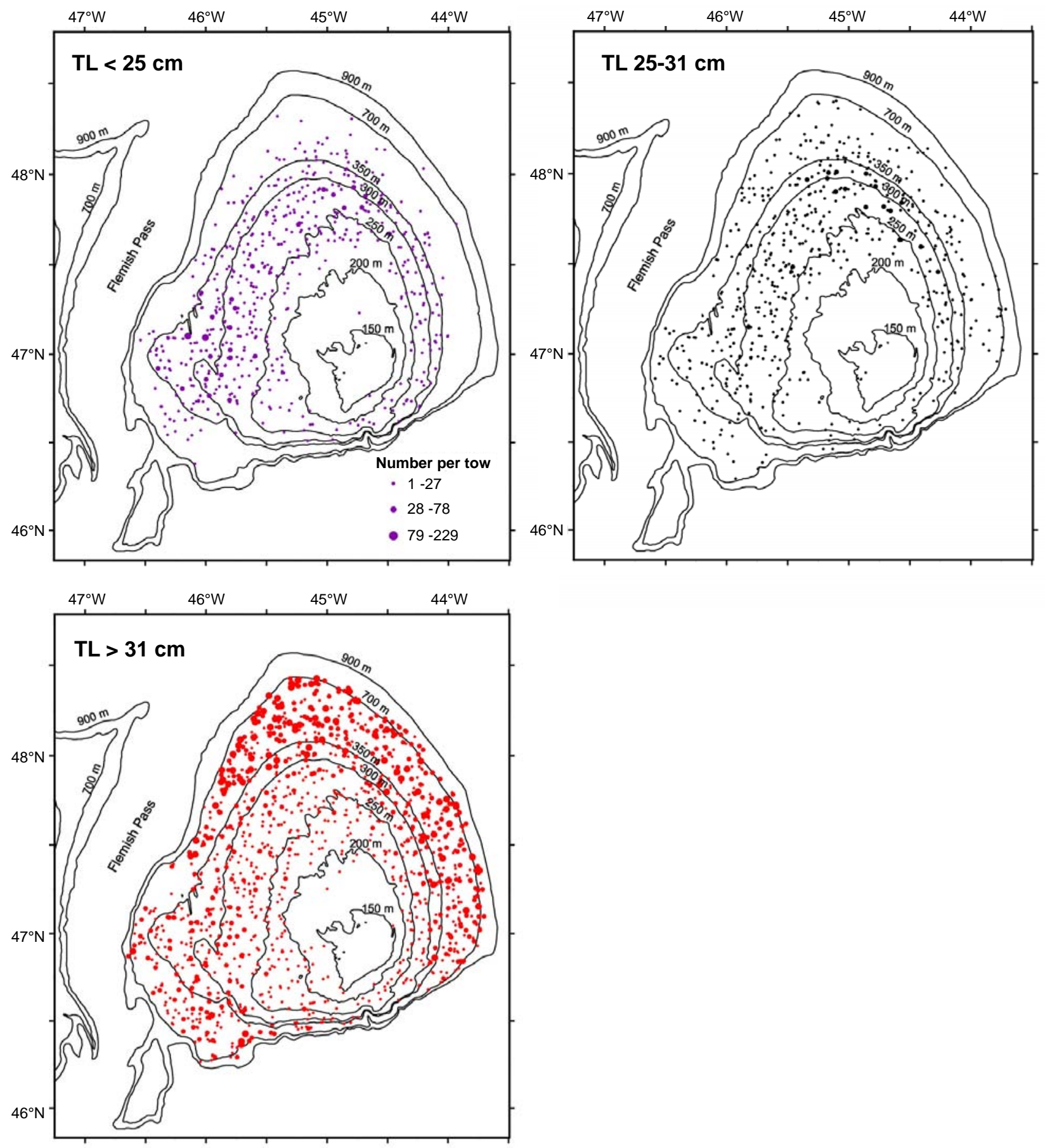

Fig. 11. Distribution of Greenland halibut abundance (number per tow) on the Flemish Cap, by length classes corresponding to ages 1, 2 and 3+, during EU bottom trawl surveys conducted in 1988-2002.

graphic variation in stock spawning characteristics (Murawski et al., 2001); b) reduced genetic diversity (Berkley et al., 2004); c) reduced areas over which eggs and larvae are dispersed and dispersal into less favorable habitats, and (d) restricted environmental conditions for growth and reproduction. For example, an anticyclonic gyre is a semi-permanent hydrologic feature on the Flemish Cap (Kudlo and Borokov, MS 1975) and its presence presumably affects primary productivity levels as well as larval dispersal and retention. During the period of 1988-2000, a well-developed anticyclonic gyre was present on the Cap during 1991, 1993 and 1995-2000, with the strongest 

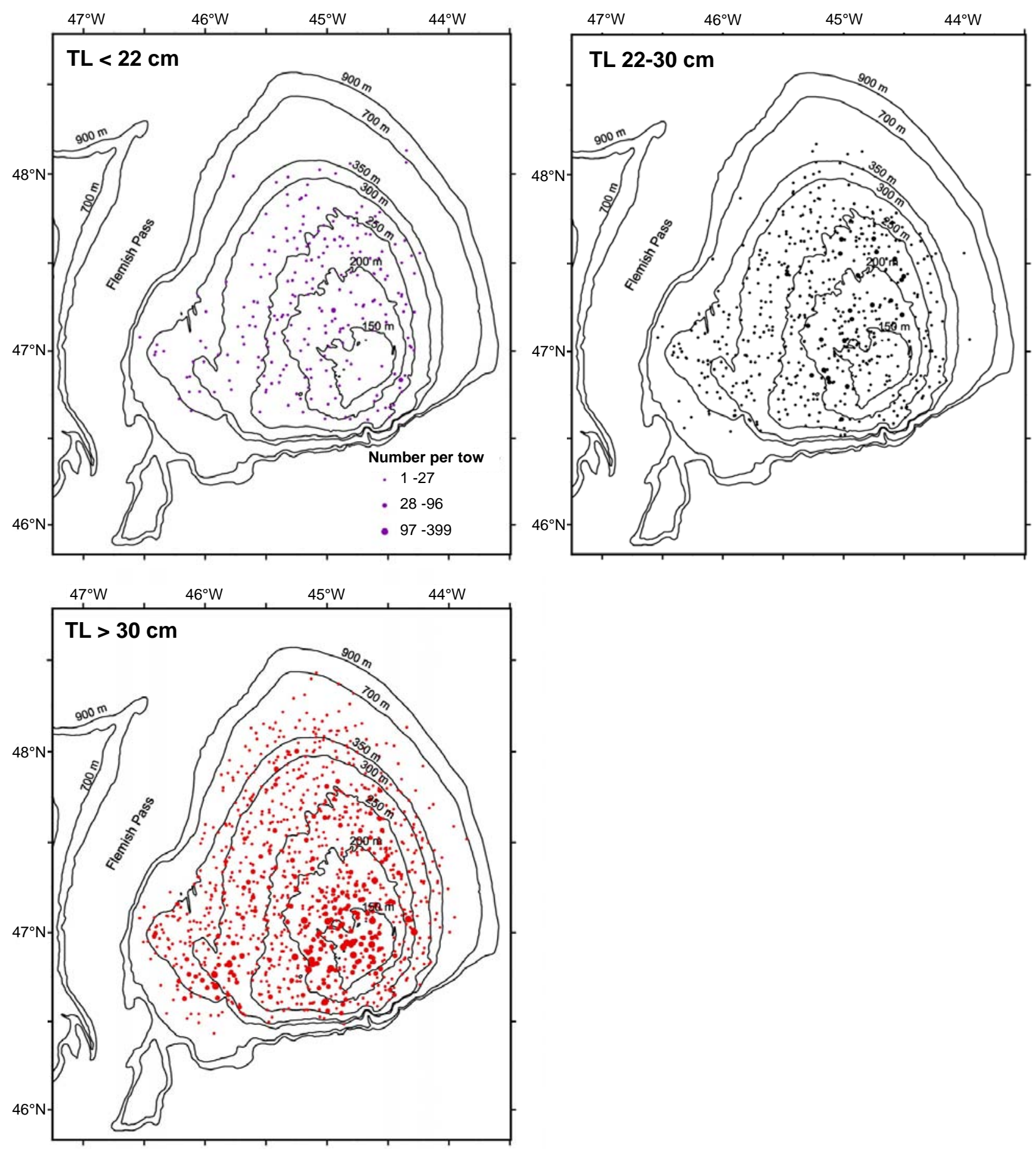

Fig. 12. Distribution of American plaice abundance (number per tow) on the Flemish Cap, by length classes corresponding to ages 1, 2 and 3+, during EU bottom trawl surveys conducted in 1988-2002.

gyre present in 1998 (Gil et al., 2004). Presence of the gyre affects thermal and salinity conditions on the Cap whereby the core contains warmer, less saline waters. During July, the amplitude of mean geostrophic velocities in the gyre tends to be highest along the eastern edge of the Cap and is associated with a southward flow off the Cap (Fig. 18). During periods when the anticyclonic gyre was well-developed, throughout most of the 1990s, the 

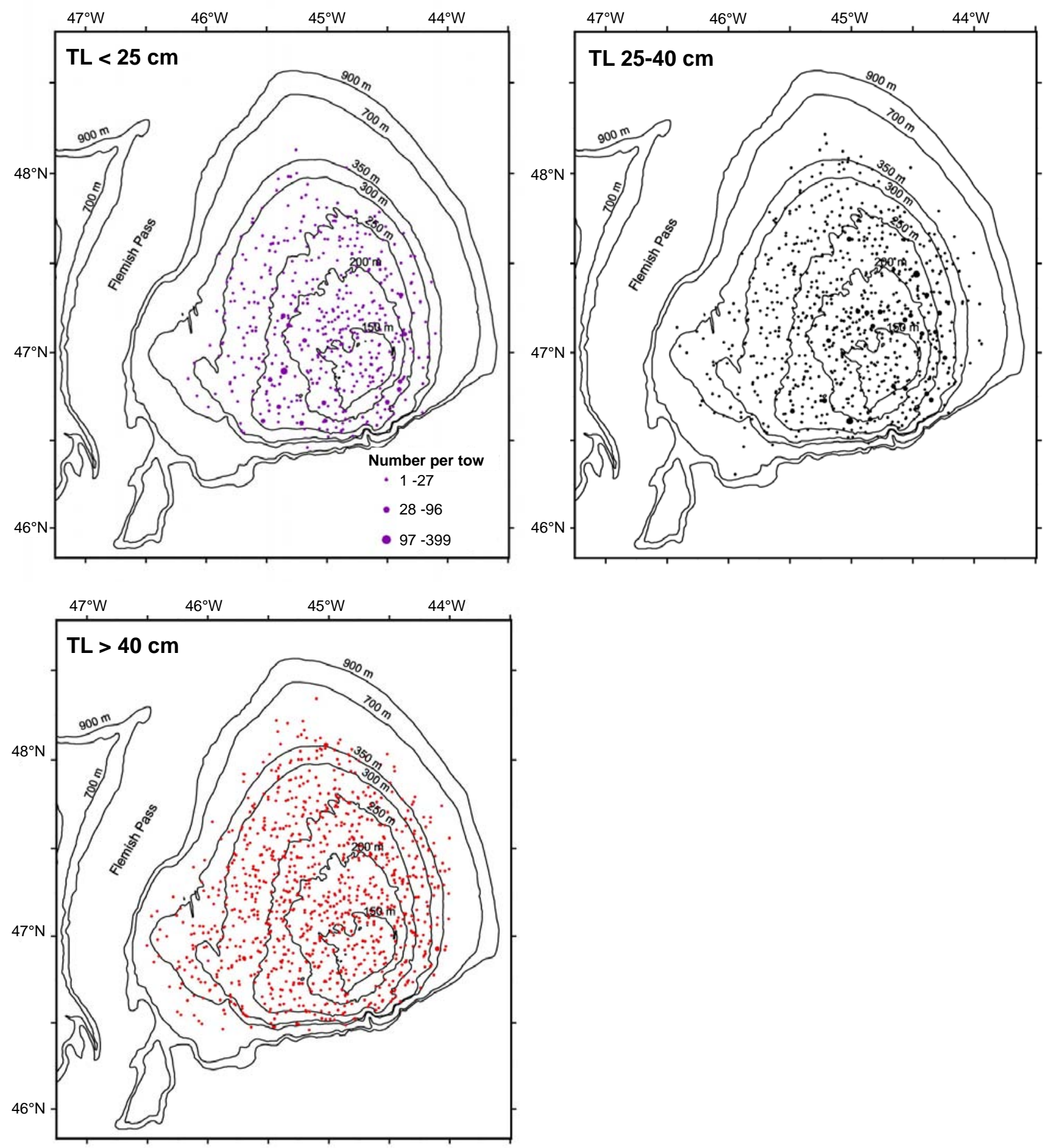

Fig. 13. Distribution of Atlantic cod abundance (number per tow) on the Flemish Cap, by length classes corresponding to ages 1, 2 and 3+, during EU bottom trawl surveys conducted in 1988-2002.

location of the high-amplitude flow off the Cap coincided with the area where cod and plaice were concentrated during this time and where the egg densities of American plaice are highest during July, near the center of the Cap at depths of 150 to $200 \mathrm{~m}$ (Nevinsky and Serebryakov, 1973). Therefore, the presence of strong gyres during the 1990s may have resulted in the loss of plaice eggs and larvae from the Flemish Cap ecosystem.

Range contraction also has important implications for stock assessments. For example, research survey biomass and abundance indices will be estimated with less 

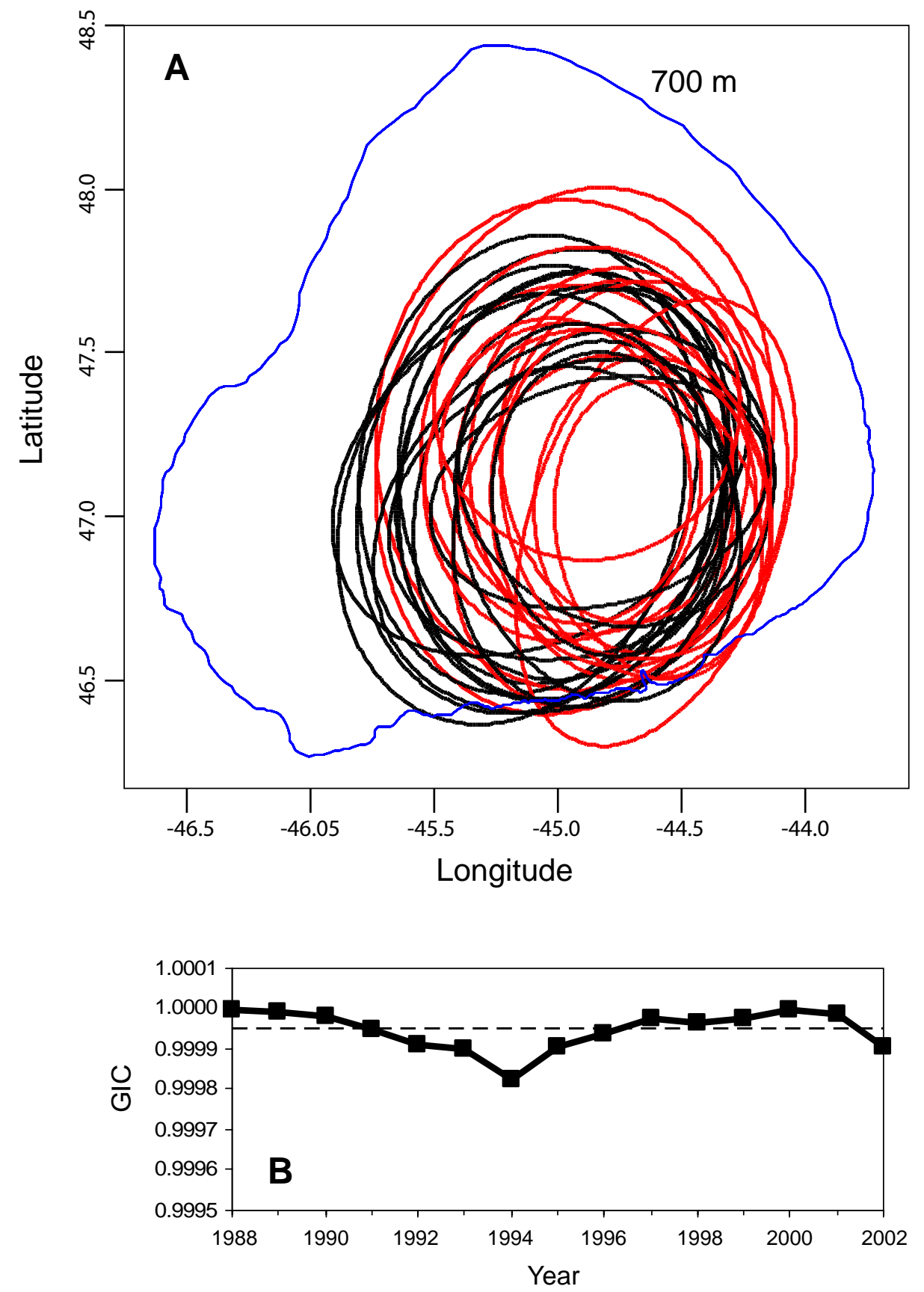

Fig. 14. Ellipses of inertia (A) indicating the annual areal distributions of Atlantic cod (red) and American plaice (black) and (B) global (GIC) indices of collocation for the two species on the Flemish Cap during 1988-2002.

precision when the spatial distribution of a population becomes distributed across a smaller area because the population will be sampled less frequently. In addition, annual trends in stratified mean weights per tow, where the mean is computed as an arithmetic mean, may mask declines in stock biomass because only a few high-density tows can have a large effect on the arithmetic mean, and as range contraction occurs, the mean becomes more dependent on fewer tows. Geometric means are more robust to infrequent high-density survey catches, but may be overly sensitive to changes in fish distribution and should therefore be compared with annual trends in 


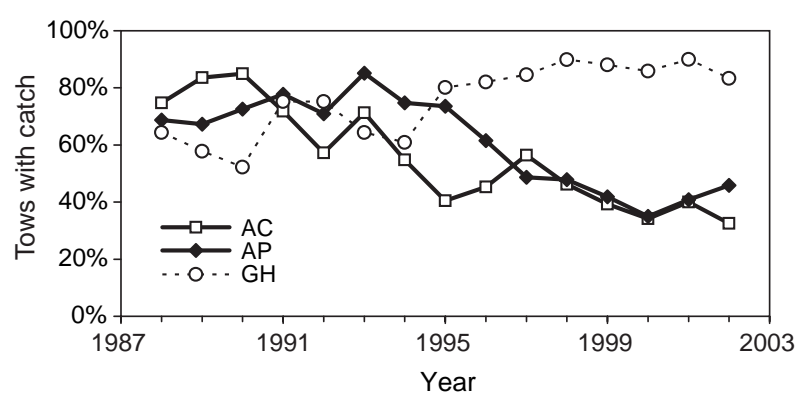

Fig. 15. Percentages of research survey tows, on the Flemish Cap, with catches of Atlantic cod (AC), American plaice (AP) or Greenland halibut (GH) during 19882002.

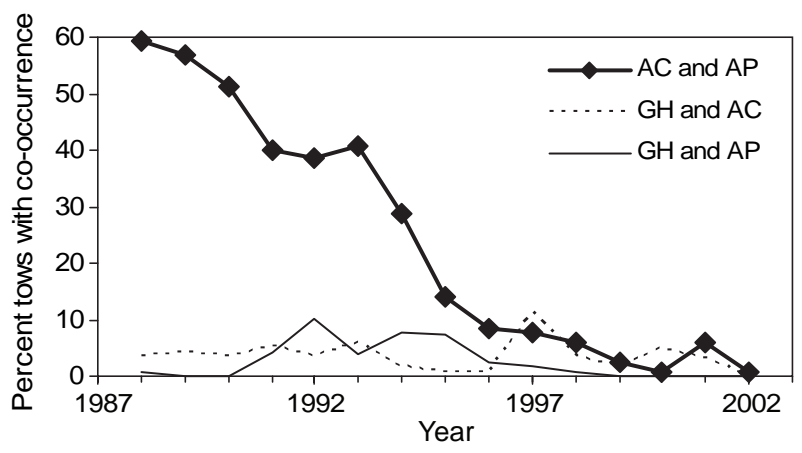

Fig. 16. Percentages of research survey tows with a co-occurrence Atlantic cod and American plaice (AC and $\mathrm{AP}$ ), Atlantic cod and Greenland halibut (AC and GH), and American plaice and Greenland halibut (AP and GH) on the Flemish Cap during 1988-2002.

arithmetic means when examining abundance or biomass trends (Hutchings, 1996). The concentration of a population in a smaller area may also result in an increased vulnerability to mobile fishing gear. Swain et al. (1994) documented density-dependent changes in the catchability of cod in survey and fishery bottom trawls. Hutchings and Myers (1994) reported a negative relationship between cod catchability and stock biomass that was attributable to catch rate differences between low-density and high-density areas of cod distribution (Hutchings, 1996). Consequently, fisheries catch-per-unit effort data should not be considered proportional to stock size for stocks that
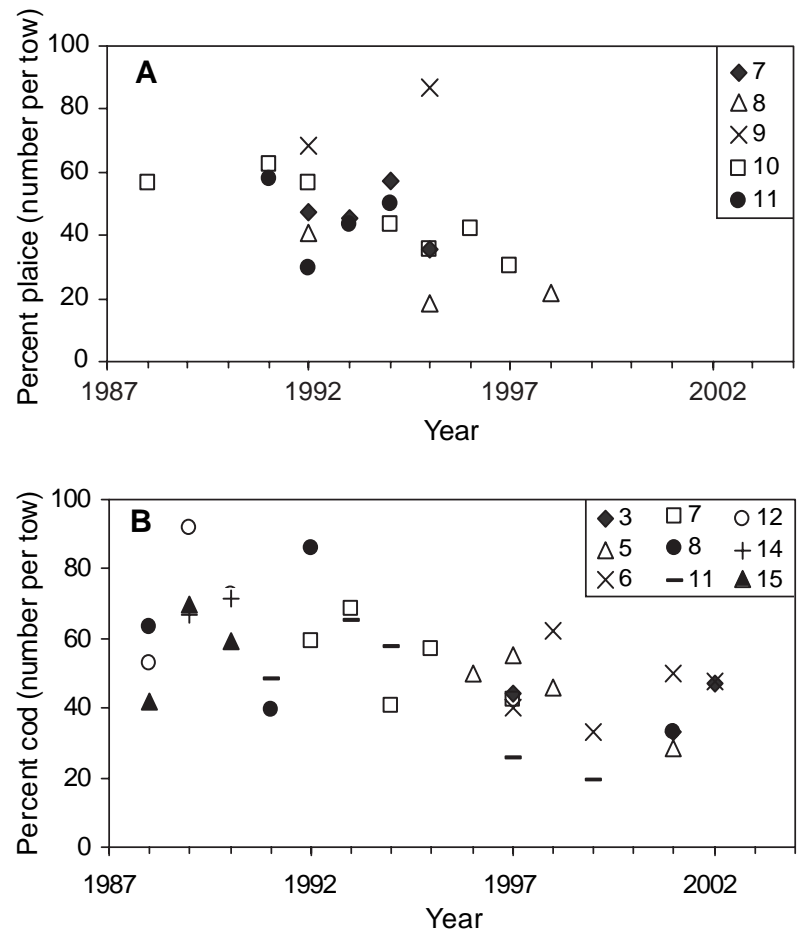

Fig. 17. Average percentages of (A) American plaice (number per tow) in survey tows with catches of both American plaice and Greenland halibut and (B) Atlantic cod in tows with catches of both Atlantic cod and Greenland halibut, by year and depth stratum, on the Flemish Cap during 1988-2002. Stratum depth increases with stratum number.

exhibit range contraction. Given the density-dependent changes that have occurred in the spatial distributions of cod and plaice on the Flemish Cap, it is recommended that alternative indices of abundance and biomass be used to monitor stock status, including geometric means and indices of spatial structure.

\section{Acknowledgements}

We would like to thank Ralph Mayo, Fred Serchuk and the anonymous reviewers whose comments and suggestions helped to improve the quality of the manuscript. 


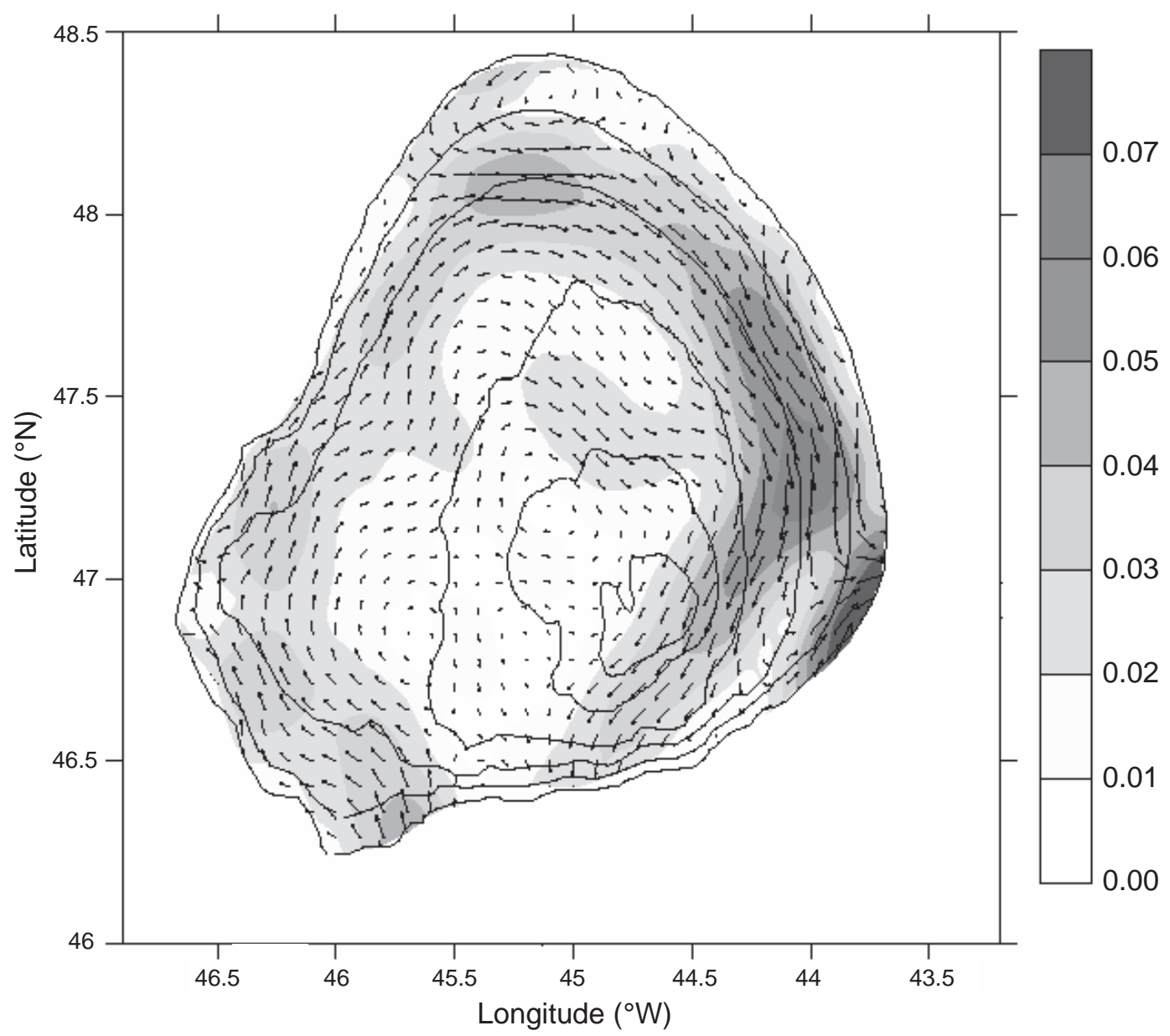

Fig. 18. Mean geostrophic velocity vectors and amplitudes (shaded areas, $\mathrm{ms}^{-1}$ ) at a depth of $10 \mathrm{~m}$, on the Flemish Cap in July, during 1988-2000 (from Gil et al., 2004).

\section{References}

ALPOIM, R., and A. ÁVILA DE MELO. MS 2004. An assessment of American Plaice (Hippoglossoides platessoides) in NAFO Division 3M. NAFO SCR Doc., No. 50, Serial No. N5003, 28 p.

ALPOIM, R., A. ÁVILA DE MELO, R. BAÑÓN, M. CASAS, S. CERVIÑO, S. JUNQUERA, I. MARTÍN, H. MURUA, X. PAZ, G. PÉREZ-GÁNDARAS, J. L. DEL RÍO, E. RODRÍGUEZ-MARÍN, F. SABORIDO-REY, E. J. DOS SANTOS, and A. VÁZQUEZ. MS 2002. Distribution and Main Characteristic of Fish Species on Flemish Cap Based on the 1988-2002 EU-Surveys in July. NAFO SCR Doc., No. 72, Serial No. N4685, 73 p.

ALVERSON, D. L., M. H. FREEBERG, J. G. POPE, and S. A. MURAWSKI. 1994. A global assessment of fisheries bycatch and discards. FAO Fish. Tech. Pap., No. 339, FAO, Rome, Italy, $233 \mathrm{p}$.

BERKELEY, S. A., M. A. HIXON, R. J. LARSON, and M. S. LOVE. 2004. Fisheries sustainability via protection of age structure and spatial distribution of fish populations. Fisheries, 29(8): 23-32.
BEZ, N., and J. RIVOIRARD. 2000. Indices of collocation between populations. In: Checkley, D. M. Jr., J. R. Hunter, L. Motos, and C. D. van der Lingen (eds.). Report of a workshop on the use of the Continuous Underway Fish Egg Sampler (CUFES) for mapping spawning habitats of pelagic fish. GLOBEC Report, 14: 48-52.

BOWERING, W. R., and D. POWER. 1995. Spatial Distribution of Greenland Halibut (Reinhardtius hippoglossoides (Walbaum)) in the Labrador-Eastern Newfoundland Area of the Canadian Northwest Atlantic. Sci. Coun. Studies, 22: $51-61$.

BOWERING, W. R., and W. B. BRODIE. 1994. Distribution, age and growth, and sexual maturity of American plaice (Hippoglossoides platessoides (Fabricius)) on Flemish Cap (NAFO Division 3M). J. Northw. Atl. Fish. Sci., 16: 49-61.

CASTONGUAY, M., C. ROLLET, A. FRECHÉT, P. GAGNON, D. GILBERT, and J.-C. BRÊTHES. 1999. Distribution changes of Atlantic cod (Gadus morhua L.) in the northern Gulf of St. Lawrence in relation to an oceanic cooling. ICES J. Mar. Sci., 56: 333-344.

CERVIÑO, S., and A.VÁZQUEZ. MS 2004. A survey-based 
assessment of cod in Division 3M. NAFO SCR Doc., No. 53, Serial No. N5006, 10 p.

COLBOURNE, E., and K. D. FOOTE. 2000. Variability of the stratification and circulation on the Flemish Cap during the decades of the 1950s and 1990s. J. Northw. Atl. Fish. Sci., 26: 103-122.

CRESSIE, N. A. C. 1993. Statistics for spatial data. Revised ed., John Wiley and Sons, New York. 900 p.

DOUBLEDAY, W. G. (editor). 1981. Manual on groundfish surveys in the northwest Atlantic. NAFO Sci. Coun. Studies, 2: $55 \mathrm{p}$.

DWYER, K. S., and R. A. BOWERING. MS 2003. Greenland Halibut (Reinhardtius hippoglossoides) in NAFO Subarea 2 and Divisions 3KLMNO: Stock Trends Based on Annual Canadian Research Vessel Survey Results during 19782000. NAFO SCR Doc., No. 51, Serial No. 4869, 57 p.

ENVIRONMENTAL SCIENCE RESEARCH INSTITUTE [ESRI]. 2001. Using ArcGIS Geostatistical Analyst. Redlands, CA. 300 p.

GIL, J., R. SÁNCHEZ, S. CERVIÑO, and D. GARABANA. 2004. Geostrophic circulation and heat flux across the Flemish Cap, 1988-2000. J. Northw. Atl. Fish. Sci., 34: 63-83.

GIL J., R. F. SÁNCHEZ, M. BLANCO, and I. REGUERA. MS 1998. Hydrodynamics associated to the confluences of Labrador and North America currents over Flemish Cap in July 1997. NAFO SCR Doc., No. 32, Serial No. N3019, 11 p.

HUTCHINGS, J. A. 1996. Spatial and temporal variation in the density of northern cod and a review of hypotheses for the stock's collapse. Can. J. Fish. Aquat. Sci., 53: 943-962.

HUTCHINGS, J. A., and R. A. MYERS. 1994. What can be learned from the collapse of a renewable resource? Atlantic cod, Gadus morhua, of Newfoundland and Labrador. Can. J. Fish. Aquat. Sci., 51: 2126-2146.

IGLESIAS, S., J. PAX, and E. DE CARDENAS. 1996. Occurrence of American plaice (Hippoglossoides platessoides) at non-habitual depths in the northwest Atlantic, 1990-93. NAFO Sci. Coun. Studies, 24: 91-95.

KUDLO, B. P., and B. A. BOROKOV. MS 1975. Circulation of waters in the ICNAF area in 1974-75. ICNAF Res. Doc., No. 79, Serial No. 3874, 14 p.

KULKA, D. W., J. S. WROBLEWSKI, and S. NARAYANAN. 1995. Recent changes in the winter distribution and movements of northern Atlantic cod (Gadus morhua Linnaeus, 1758) on the Newfoundland-Labrador Shelf. ICES J. Mar. Sci., 52: 889-902.

MORGAN, M. J. 1993. Ration level and temperature preference of American plaice. Mar. Behav. Physiol., 24: 117-122.

MORGAN, M. J., and W. R. BOWERING. MS 2004. Is there mixing of American plaice populations in the Flemish Pass? NAFO SCR Doc., No. 62, Serial No. N5023, 9 p.

1997. Temporal and geographic variation in maturity at length and age of Greenland halibut (Reinhardtius hippoglossoides) from the Canadian northwest Atlantic with implications for fisheries management. ICES J. Mar. Sci., 54: 875-885.

MORGAN, M. J., and W. B. BRODIE. 1991. Seasonal distribu- tion of American plaice on the northern Grand Banks. Mar. Ecol. Prog. Ser., 75: 101-107.

MURAWSKI, S. A., P. J. RAGO, and E. A. TRIPPEL. 2001. Impacts of demographic variation in spawning characteristics on reference points for fishery management. ICES J. of Mar. Sci., 58: 1002-1014.

NEVINSKY, M. M., and V. P. SEREBRYAKOV. 1973. American plaice, Hippoglossoides platessoides platessoides Fabr., spawning in the northwest Atlantic area. ICNAF Res. Bull., 10: $23-36$.

NORTHWEST ATLANTIC FISHERIES ORGANIZATION [NAFO]. 1994. Meeting Proceedings of the General Council and Fisheries Commission for 1993, 134 p.

1999. Meeting Proceedings of the General Council and Fisheries Commission for 1998, 238 p.

2003. Scientific Council Reports 2002/2003, 383 p.

PITT, T. K. 1963. Vertebral numbers of American plaice, Hippoglossoides platessoides (Fabricius), in the Northwest Atlantic. J. Fish. Res. Board Can., 20: 1159-1181.

RIVOIRARD, J., J. SIMMONDS, K. G. FOOTE, and N. BEZ. 2000. Geostatistics for estimating fish abundance. Blackwell Science Ltd., London, UK, 206 p.

SAS INSTITUTE INC. 1985. SAS User's Guide: Statistics, Version 5 Edition. Cary, NC, 956 p.

SABORIDO, F., and A. VÁZQUEZ. MS 2003. Results from bottom trawl survey on Flemish Cap of July 2002. NAFO SCR Doc., No. 42, Serial No. N4860, 41 p.

SWAIN, D. P., and D. L. KRAMER. 1995. Annual variation in temperature selection by Atlantic cod (Gadus morhua) in the southern Gulf of St. Lawrence and its relation to population size. Mar. Ecol. Prog. Ser., 116: 11-23.

SWAIN, D. P., and R. MORIN. 1996. Relationships between geographic distribution and abundance of American plaice (Hippoglossoides platessoides) in the southern Gulf of St. Lawrence. Can. J. fish. Aquat. Sci., 53: 106-119.

SWAIN, D. P., G. A. NIELSEN, A. F. SINCLAIR, and A. G. CHOUINARD. 1994. Changes in catchability of Atlantic cod (Gadus morhua) to an otter-trawl fishery and research survey in the southern Gulf of St. Lawrence. ICES J. Mar. Sci., 51: 493-504.

SWAIN, D. P., G. A. CHOUINARD, R. MORIN, and K. F. DRINKWATER. 1998. Seasonal variation in the habitat associations of Atlantic cod (Gadus morhua) and American plaice (Hippoglossoides platessoides) from the southern Gulf of St. Lawrence. Can J. Fish. Aquat. Sci., 55: 2548-2561.

TEMPLEMAN, W. 1973. Distribution and abundante of Greenland halibut, Reinhardtius hippoglossoides (Walbaum), in the northwest Atlantic. ICNAF Res. Bull., 10: 83-98.

TORRES, P., E. RODRIGUEZ-MARIN, and I. LOUREIRO. 2000. Preliminary results from feeding analysis for the most abundant demersal fishes in Flemish Cap during summer (1993-2000). NAFO SCR Doc., No. 60, Serial No. N4302, 9 p.

WARREN, W. G. 1997. Changes in the within-survey spatiotemporal structure of the northern cod (Gadus morhua) population, 1985-1992. Can. J. Fish. Aquat. Sci., 54(Suppl. 1): $139-148$. 